\title{
Effectiveness of Virtual Reality and Interactive Simulators on Dental Education Outcomes: Systematic Review
}

\author{
Rania Moussa ${ }^{1} \quad$ Amira Alghazaly ${ }^{2} \quad$ Nebras Althagafi ${ }^{3}$ \\ ${ }^{1}$ Department of Substitutive Dental Sciences, College of Dentistry, \\ Taibah University, Medinah, Saudi Arabia \\ 2Department of Restorative Dental Sciences, College of Dentistry, \\ Taibah University, Medinah, Saudi Arabia \\ ${ }^{3}$ Department of Pediatric Dentistry and Orthodontics, College of \\ Dentistry, Taibah University, Medinah, Saudi Arabia
}

\author{
Rawah Eshky ${ }^{3}$ Sary Borzangy ${ }^{1}$
}

Eur J Dent 2022;16:14-31.

\begin{abstract}
In recent years, virtual reality and interactive digital simulations have been used in dental education to train dental students before interacting with real patients. Scientific evidence presented the application of virtual technology in dental education and some recent publications suggested that virtual and haptic technologies may have positive effects on dental education outcomes. The aim of this systematic review was to determine whether virtual technologies have positive effects on dental education outcomes and to explore the attitudes of dental students and educators toward these technologies. A thorough search was conducted in PubMed, Scopus, MEDLINE (via EBSCO), The Cochrane Library (via Wiley), Web of Science Core Collection (via Thomson Reuters), and Dentistry and Oral Science source (via EBSCO) using the keywords (student, dental) AND (education, dental) AND (virtual reality) OR (augmented reality) OR (haptics) OR (simulation) AND (dentistry) OR (dental medicine). The qual-

\section{Keywords}

- augmented reality

- simulation

- dental education

- haptics

- students

- dental

- virtual reality

- education ity of the reported information was assessed following the Preferred Reporting Items for Systematic Review and Meta-Analysis (PRISMA) statement for systematic reviews. A total of 73 publications were considered for this review. Fifty-two of the selected studies showed significant improvement in educational outcomes and virtual technologies were positively perceived by all the participants. Within the limitations of this review, virtual technology appears to improve education outcomes in dental students. Further studies with larger samples and longer term clinical trials are needed to substantiate this potential positive impact of various virtual technologies on dental education outcomes.
\end{abstract}

\section{Introduction}

In recent years, virtual reality (VR) simulations have been employed in dental education as an adjunctive to the traditional skill training curriculum to train dental students

published online August 24, 2021
DOI https://doi.org/

$10.1055 / \mathrm{s}-0041-1731837$ ISSN $1305-7456$ before interacting with actual patients., ${ }^{1,2}$ Dental education differs from any other form of medical education as it is a combination of theory, laboratory, and clinical practice. The challenge in dental education arises from the fact that theoretical knowledge acquisition requires spatial imagination

(C) 2021. The Author(s).

This is an open access article published by Thieme under the terms of the Creative Commons Attribution License, permitting unrestricted use, distribution, and reproduction so long as the original work is properly cited. (https:// creativecommons. org/licenses/by/4.0/).

Thieme Medical and Scientific Publishers Pvt. Ltd. A-12, 2nd Floor, Sector 2, Noida-201301 UP, India 
and the patient-centered training on traditional mannequin simulation does not resemble realistic clinical situations. ${ }^{3}$ Preclinical and clinical training is of paramount importance for developing fine motor skills to prepare dental students to engage in the dental profession. Many of the required dental education competency skills are challenging to acquire, and mandates repeated training and long practice. ${ }^{4}$ Since the breakthrough of the novel coronavirus SARS-Co-V-2 (severe acute respiratory syndrome coronavirus 2 ) in late $2019,{ }^{5}$ all essential activities were affected, calling for social distancing, and the traditional dental teaching models of one-on-one pedagogical design had to be partially replaced by digital or virtual setups to avoid the gathering of the youth in closed spaces.

VR is gaining acknowledgment as a valuable tool for training dental students, and its use by dental schools is rising worldwide. ${ }^{6}$ VR is defined as a computer-generated medical simulation of a three-dimensional (3D) image or environment that uses software to create an immersive computer-generated environment. Users put on a head-mounted display that places them inside an experience, where they can engage with the setting and virtual characters in a way that feels real. VR could be beneficial in dental education, permitting a patient noncontact training environment. ${ }^{1,2}$

Augmented reality (AR) is a superimposition of computer-generated graphics over a real-life scene. It differs from VR, which does not demonstrate natural conditions. AR refers to a form of technology that integrates both real and virtual elements in a combined experience and allows learners to visualize complex spatial relationships, abstract concepts, and experience phenomena that might have been impossible in the real world, especially in surgical procedures coaching. ${ }^{7,8}$ Immersive virtual reality (IVR) is one form of AR where the user interacts with a digital 3D environment recreated through 360 degrees actual records. ${ }^{9}$

Haptic technology (HT) is a more recent simulation that involves tactile sensation while interacting with computer-generated objects. Haptics means the sense of touch and consists of the science of incorporating the interaction with the external environment through contact. ${ }^{2}$ Implementing these technologies in dental education motivated designers to create virtual teeth with and without pathology, multilayered and featured with different mechanical hardness for enhanced reality..$^{10,11}$

The applications of VR in dental education attracted the attention of researchers even in the early experimental stages. ${ }^{7}$ It was suggested that it could enhance dental education compared with traditional teaching, ${ }^{1}$ especially in the training of restorative dentistry, ${ }^{12,13}$ and dental surgery, 14,15 although it may expand to include endodontics and orthodontics. ${ }^{16-18}$ VR enabled the delivery of distant online lectures through 3D VR workplace. The flexibility of the technology allowed the attendees' active contribution and facilitated 3D understanding of surgery and related anatomy, despite the limitation of technical issues. ${ }^{19}$ However, the results of VR effectiveness in dental education outcomes are controversial. Thus, this systematic review aimed to evaluate the effectiveness of VR simulations on dental education outcomes. The assessed results of VR interventions were knowledge, clinical skills, attitude, and satisfaction of both learners and educators.

\section{Methods}

\section{Protocol and Eligibility Criteria}

This systematic review was conducted according to the Preferred Reporting Items for Systematic Review and Meta-Analysis (PRISMA) guidelines. ${ }^{20} \mathrm{~A}$ modified PICOS search was defined, and studies that fulfilled the following criteria were selected:

1. Population (P): Undergraduate and postgraduate dental learners enrolled in any dental-related education or training program were included in the review.

2. Intervention (I): Virtual simulation teaching and assessment methods including but not limited to VR, AR, and HT.

3. Primary outcomes (O): Include clinical competencies measured pre or post intervention represented in learners' knowledge and manual skills. Secondary outcomes included students' and educators' perceptions of VR designs.

4. Study design (S): the review applied no limits for the study design.

5. Comparison (C): was not a mandatory item to include a study in this review.

\section{Information Sources}

A systematic electronic search was performed limited to English language articles published between January 2010 to the end of March 2021. Studies were identified by searching the following electronic databases for relevant studies: PubMed, Scopus, MEDLINE (via EBSCO), The Cochrane Library (via Wiley), Web of Science Core Collection (via Thomson Reuters), and Dentistry and Oral Science source (via EBSCO).

The following search terms were used for identification of eligible studies: (student, dental) AND (education, dental) AND (VR) OR (AR) OR (haptics) OR (simulation) AND (dentistry) OR (dental medicine). Keywords were adjusted for use with each of the databases mentioned earlier. Further electronic search of the relevant articles in the Journal of Dental Education and the European Journal of Dental Education was performed while running our electronic search. The bibliographies of the revealed full texts, were manually searched for additonal studies.

\section{Study Selection}

The search results were combined in a single Mendeley library (Mendeley Desktop v1.19.6) and duplicates were excluded. Two authors independently screened titles, abstracts to identify potentially eligible studies. Exclusion criteria included preliminary reports, reports without an underlying study design, and studies describing the software or hardware of the virtual technology. One co-author retrieved full-text versions of the selected studies. Selected publications were independently reviewed by two investigators. 


\section{Data Collection}

Customized forms following the guidelines of the Cochrane Consumers and Communication Review Group template for review authors, ${ }^{21}$ were used to record the following data from the selected studies:

- Characteristics of the study: study design, research country, and time of intervention (before-after).

- Characteristics of the study participants: number of participants, stage of education (under or postgraduate), and year of study.

- Virtual intervention applied: dental specialty where simulation was used, type of the system, and the source of virtual simulations: whether access to virtual simulation was from home or at academic laboratories.

- The outcome investigated; subjective or objective assessment, and the tools used to measure the output.

- Results of the selected studies.

\section{Results}

\section{Studies Included}

The study selection process for inclusion in this review is summarized in - Fig. 1 (diagram flow). The database search strategy identified 498 potentially eligible references. Twelve additional articles were included after review of references. Duplicates were excluded. After screening titles, abstracts, 437 articles were excluded applying the exclusion criteria. Eventually 73 studies were included in the review that included 5,275 participants.

The retrieved studies were categorized according to the field of dental education in which VR was applied. -Fig. 2 shows the percentile representation of each dental specialty in the selected studies.

\section{Description of the Study Characteristics Restorative Dentistry}

Twenty-three of the selected studies applied VR in restorative dentistry with total included participants, $n=2,201$, in which $62.1 \%, n=1,367$ were first year dental students. The detailed characteristics of the included studies are shown in - Table 1. HT was the most used in 18 of the selected studies, ${ }^{12,22-38}$ VR simulator in three studies ${ }^{39-41}$ and $A R,{ }^{13}$ and interactive video games, ${ }^{42}$ one study each. Access to all these technologies was through academic laboratories except in one study. ${ }^{13}$ In the selected studies, students' manual skills was the most common tested outcome represented in cavity preparations in $52.17 \%, n=12,13,24,25,28-30,33-35,38,39,41$ or geometric figures $34.78 \%, n=8 .^{12,22,23,26,27,31,32,36}$ Other manual skills tested were dentin etching and resin bonding, ${ }^{42}$ and zinc phosphate cement application, ${ }^{40}$ one study each. Four studies assessed VR on theoretical knowledge. ${ }^{13,37,40,42}$ Results showed significant difference in 14 of the selected studies in manual clinical skills ${ }^{12,13,23,27,29-31,34-36,38-41}$ and two studies in theoretical knowledge. ${ }^{37,40}$

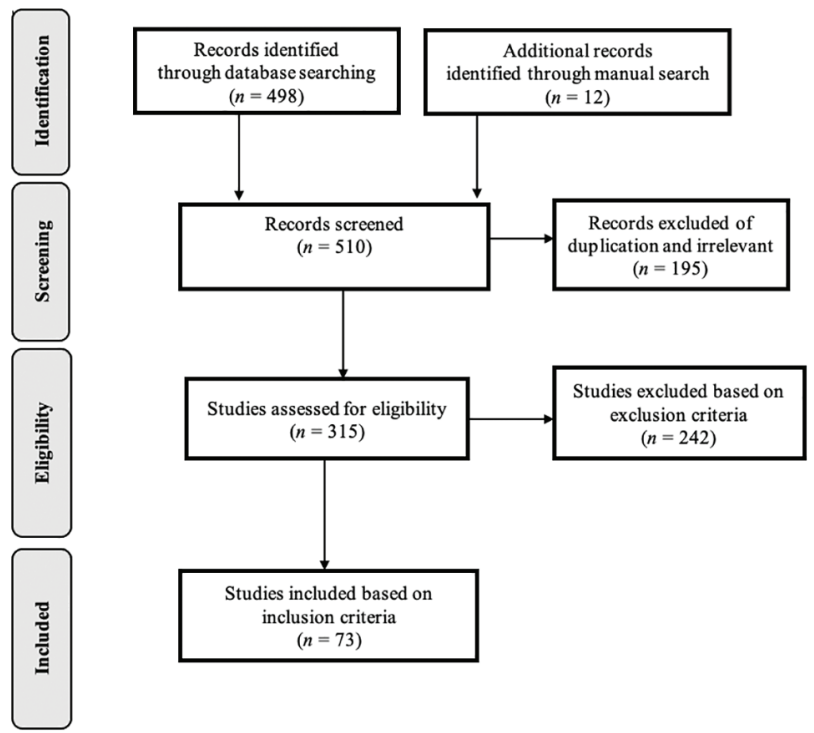

Fig. 1 Preferred Reporting Items for Systematic Reviews and Meta-Analyses (PRISMA) diagram flow of the selection process.

\section{Endodontics}

Six of the selected studies applied VR in endodontic with total included participants, $n=189$. Characteristics of the selected studies are shown in - Table 2. HT was applied for access opening in three studies, ${ }^{43-45}$ and surgical apicectomy in two studies. ${ }^{14,15}$ VR simulation was used in one study to teach root canal anatomy. ${ }^{46}$ Four studies showed significant better results of the virtual technology. ${ }^{14,43,44,46}$ Students highly appreciated virtual training in one study, ${ }^{15}$ although suggested modifications in spatial registration precision, FFB of different tissues, and more realistic models in another study. ${ }^{45}$

\section{Oral and Maxillofacial Surgery}

Nine of the selected studies applied VR technologies in oral and maxillofacial surgery education with total included participants, $n=730$. Characteristics of the selected studies are shown in - Table 3. Virtual patient (VP) simulation was applied in four studies, ${ }^{47-50}$ AR in three studies, ${ }^{51-53}$ and IVR in two studies. ${ }^{54,55}$ Results showed significant differences in all the selected studies except one study. ${ }^{53}$ Participants positively appreciated the value of the VR in education, and the test groups reported significantly higher self-confidence.

\section{Prosthodontics}

Thirteen of the selected studies applied VR in prosthodontics with total included participants, $n=815$. Characteristics of the selected studies are shown in - Table 4.

All studies applied VR in fixed prosthodontics training and evaluation, except two studies: one in preclinical removable partial denture prosthodontics course, ${ }^{56}$ and the second in teaching occlusion. ${ }^{57}$ Manual skills of tooth preparation was evaluated in nine of the selected studies, ${ }^{58-67}$ acquired knowledge in one study, ${ }^{57}$ and students' perception in three 


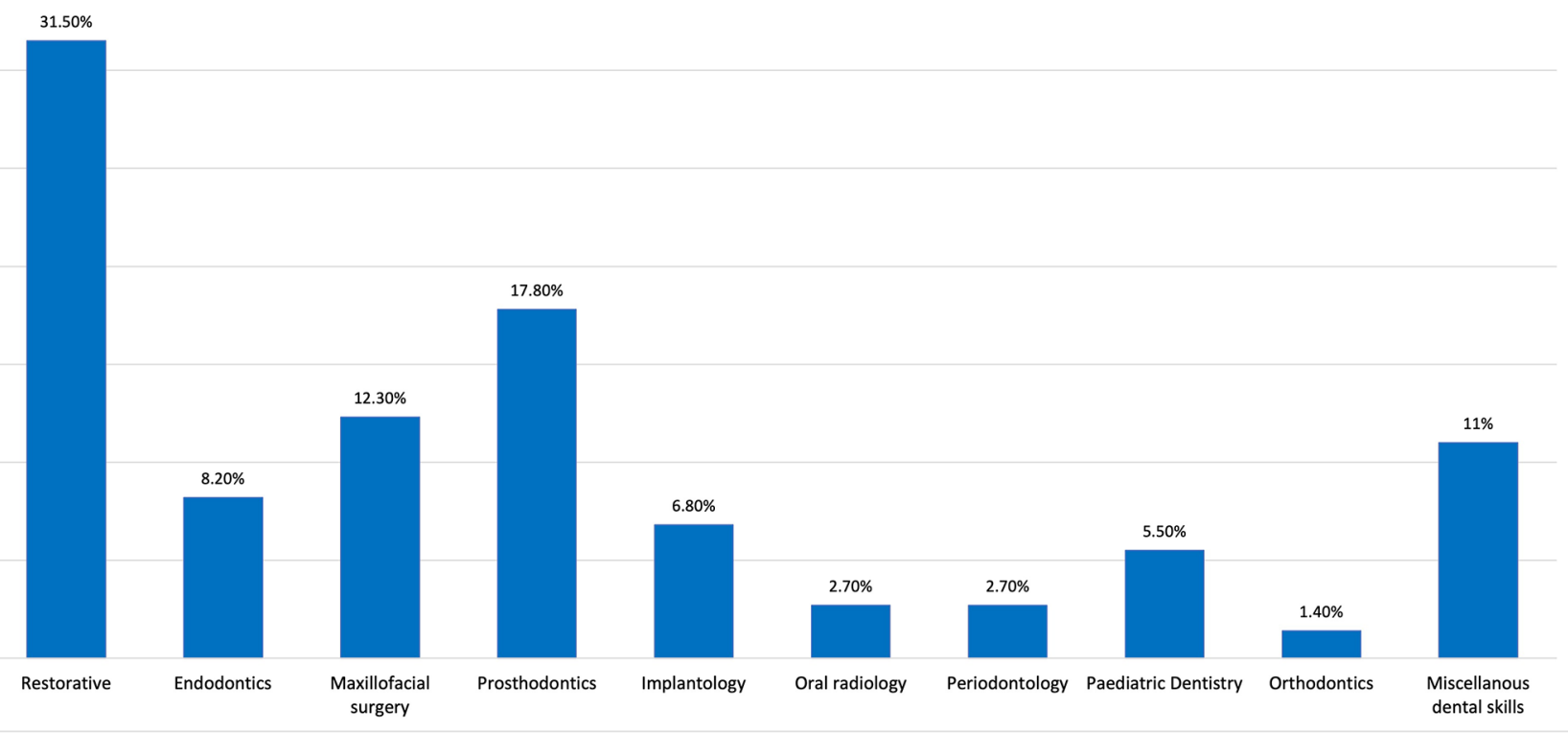

Fig. 2 Bar chart percentile representation of each dental specialty in the selected studies.

studies. ${ }^{3,56,59}$ Nine studies reported significant statistical differences of the VR scores. . $^{5,58,60-67}$

\section{Implantology}

Five of the selected studies applied dental implant education with total included participants, $n=351$. Characteristics of the selected studies are shown in - Table 5. Implant placement manual skills were assessed in four studies, ${ }^{68-71}$ and theoretical knowledge in two studies. ${ }^{70,72}$ Results of all the selected studies showed significant improvement of implant education outcomes in both clinical skills and theoretical knowledge.

\section{Oral and Maxillofacial Radiology}

Two studies reported the application of VR in dental radiology education with total included participants, $n=84$. Characteristics of the selected studies are shown in - Table 6. Both studies reported significant improvement of students' skill to interpret spatial information in radiographs and acquisition of theoretical knowledge, although OSCE scores were insignificantly different. ${ }^{73,74}$

\section{Periodontology}

Two studies considered HT in periodontology with total included participants, $n=55$. Characteristics of the selected studies are shown in - Table 7. HT features were evaluated as high realistic in periodontal tasks, ${ }^{75}$ and significantly improved pocket probing scores. ${ }^{76}$

\section{Pediatric Dentistry}

Four studies applied VR in pediatric dentistry with total included participants, $n=295$. Characteristics of the selected studies are shown in -Table 8. Pediatric VP significantly improved behavior and communication management, ${ }^{77}$ and AR significantly improved infiltrative anesthesia administration time. ${ }^{78}$ Students highly perceived HT in the training on pediatric clinical tasks, ${ }^{79}$ and VR superimposing $3 \mathrm{D}$ holograms in local anesthesia administration. ${ }^{80}$

\section{Orthodontics}

One study considered VR in orthodontics education. The study applied Scenario Based Learning Interactive software (SBLi) on orthodontics postgraduates, $n=9$. Participants reported a high acceptance rate of the package, greater confidence applying the clinical skills covered in the modules, and reduced contact time. ${ }^{81}$

\section{Miscellaneous Dental Skills}

Eight studies applied virtual strategies in teaching miscellaneous dental skills; critical thinking, ${ }^{82}$ professionalism, ${ }^{83}$ scientificwriting ${ }^{84}$ knowledge of homedental practice, ${ }^{85}$ head and neck anatomy, ${ }^{86}$ dental morphology, ${ }^{87}$ dental diagnosis, ${ }^{88}$ and social aspects of dental care delivery. ${ }^{89}$ Total included participants were $n=543$. Characteristics of the selected studies are shown in - Table 9.

\section{Discussion}

The application of VR in dental education has evolved increasingly, and there is significant scientific evidence that describes different virtual setups in different dental educational modules. However, the actual significance of VR simulation on dental education outcomes is not entirely clear. Earlier, VR may have been considered luxurious or optional, nevertheless in the shadow of the global COVID-19 (coronavirus disease 2019) pandemic, dental students need to proceed with their curriculum without any setbacks of the physical presence. VR may provide an opportunity for dental students to build and retain theoretical and clinical dental expertise remotely. 
Table 1 Characteristics of the selected studies in restorative dentistry

\begin{tabular}{|c|c|c|c|c|c|c|c|}
\hline $\begin{array}{l}\text { S. } \\
\text { no }\end{array}$ & $\begin{array}{l}\text { Author, Year, } \\
\text { Country }\end{array}$ & VR system & Participants & $\begin{array}{l}\text { Study } \\
\text { design }\end{array}$ & Tool of assessment & Tested outcome & Results \\
\hline 1 & $\begin{array}{l}\text { Urbankova } \\
2010, \text { UK }^{39}\end{array}$ & $\begin{array}{l}\text { Adjunctive } \\
\text { computer- } \\
\text { ized dental } \\
\text { simulator } \\
\text { (CDS) }\end{array}$ & $\begin{array}{l}\text { (75) 1st year } \\
\text { DS }\end{array}$ & $\mathrm{RCT}$ & $\begin{array}{l}\text { Class I and II cavity } \\
\text { preparation }\end{array}$ & $\begin{array}{l}\text { Timing on exam } \\
\text { performance }\end{array}$ & $\begin{array}{l}\text { CDS significantly better } \\
\text { than controls on exams } \\
1 \text { and } 2 \text { but not signifi- } \\
\text { cant on exam } 3\end{array}$ \\
\hline 2 & $\begin{array}{l}\text { Urbankova } \\
\text { and } \\
\text { Engebretson } \\
2011, \text { UK}^{22}\end{array}$ & $\begin{array}{l}\text { Haptic } \\
\text { simulator }\end{array}$ & $\begin{array}{l}\text { (39) 1st year } \\
\text { DS }\end{array}$ & CS & $\begin{array}{l}\text { - Perceptual ability } \\
\text { test (PAT) } \\
\text { - Geometric figures } \\
\text { haptic exercises }\end{array}$ & $\begin{array}{l}\text { Accuracy, time, and } \\
\text { success rate }\end{array}$ & $\begin{array}{l}\text { Correlation is nonsig- } \\
\text { nificant between PAT } \\
\text { and exam scores, and } \\
\text { significant between } \\
\text { exam scores, time and } \\
\text { accuracy }\end{array}$ \\
\hline 3 & $\begin{array}{l}\text { Amer et al } \\
\text { 2011, United } \\
\text { States }^{42}\end{array}$ & $\begin{array}{l}\text { Interactive } \\
\text { dental video } \\
\text { game to } \\
\text { teach dentin } \\
\text { bonding }\end{array}$ & $\begin{array}{l}\text { (80) 1st year } \\
\text { DS }\end{array}$ & $\mathrm{RCT}$ & $\begin{array}{l}\text { - Pre and post written } \\
\text { examination } \\
\text { - Shear bond strength } \\
\text { test } \\
\text { - Students' perception }\end{array}$ & $\begin{array}{l}\text { Knowledge and clinical } \\
\text { skills }\end{array}$ & $\begin{array}{l}\text { No significant differ- } \\
\text { ence in knowledge or } \\
\text { clinical skills except } \\
\text { in wetness of dentine } \\
\text { following etching. } \\
\text { Students accred- } \\
\text { ited the method of } \\
\text { teaching }\end{array}$ \\
\hline 4 & $\begin{array}{l}\text { Urbankova et } \\
\text { al 2013, UK } K^{31}\end{array}$ & $\begin{array}{l}\text { Complex } \\
\text { haptic } \\
\text { Simulator }\end{array}$ & $\begin{array}{l}\text { (39) 1st year } \\
\text { DS }\end{array}$ & CST & $\begin{array}{l}\text { - Haptic exercise of } \\
\text { geometric figures } \\
\text { - Plastic tooth } \\
\text { preparations }\end{array}$ & $\begin{array}{l}\text { - Accuracy and time } \\
\text { - Quality of } \\
\text { plastic-tooth } \\
\text { preparation }\end{array}$ & $\begin{array}{l}\text { Number of failures } \\
\text { in haptic exercises } \\
\text { showed significant } \\
\text { predictor of examina- } \\
\text { tion scores }\end{array}$ \\
\hline 5 & $\begin{array}{l}\text { Bakr et } \\
\text { al } 2014, \\
\text { Australia }^{32}\end{array}$ & $\begin{array}{l}\text { Simodont } \\
\text { haptic } \\
\text { (3D-VR) }\end{array}$ & $\begin{array}{l}\text { (42) 2nd year } \\
\text { DS }\end{array}$ & $\begin{array}{l}\text { CCO } \\
\text { Early } \\
\text { or late } \\
\text { haptic } \\
\text { training }\end{array}$ & $\begin{array}{l}\text { pre- and post-psy- } \\
\text { chomotor skills test } \\
\text { - Pre- and post-ex- } \\
\text { perimental and flow } \\
\text { questionnaires } \\
\text { - Class II amalgam } \\
\text { preparation on per- } \\
\text { manent 1st molar } \\
\end{array}$ & $\begin{array}{l}\text { - \% of target } \\
\text { area prepared. } \\
\text { Expectations, and } \\
\text { attitudes. Quality of } \\
\text { prepared cavity }\end{array}$ & $\begin{array}{l}\text { No significant differ- } \\
\text { ence in practical test } \\
\text { (pre and post) between } \\
\text { groups. The system } \\
\text { was highly accepted by } \\
\text { the students }\end{array}$ \\
\hline 6 & $\begin{array}{l}\text { Koo et al } \\
2015, \text { United } \\
\text { States }^{33}\end{array}$ & $\begin{array}{l}\text { Haptic device } \\
\text { (SensAble) }\end{array}$ & $\begin{array}{l}\text { (34) 2nd year } \\
\text { DS }\end{array}$ & $\mathrm{RCT}$ & $\begin{array}{l}\text { - Class II amalgam and } \\
\text { class III resin } \\
\text { - Questionnaire }\end{array}$ & $\begin{array}{l}\text { - Cavity outline } \\
\text { and integrity of } \\
\text { adjacent tooth. } \\
\text { Subjective } \\
\text { evaluation of the } \\
\text { simulation }\end{array}$ & $\begin{array}{l}\text { Non-statistically } \\
\text { significant post haptic } \\
\text { scores. Game-feature } \\
\text { of the device made the } \\
\text { learning experience } \\
\text { more interesting }\end{array}$ \\
\hline 7 & $\begin{array}{l}\text { Cox et al } \\
2016, \mathrm{UK}^{34}\end{array}$ & $\begin{array}{l}\text { HapTEL } \\
\text { system }\end{array}$ & $\begin{array}{l}\text { (101) 1st } \\
\text { year DS }\end{array}$ & CS & $\begin{array}{l}\text { Virtual caries lesions } \\
\text { with increased } \\
\text { complexity }\end{array}$ & $\begin{array}{l}\text { - \% of caries } \\
\text { removed, healthy } \\
\text { tissue remaining, } \\
\text { pulp exposure, and } \\
\text { drilling time }\end{array}$ & $\begin{array}{l}\text { \% caries tissue } \\
\text { removed, healthy } \\
\text { tissue remaining, } \\
\text { and pulp exposure } \\
\text { improved for over } 90 \%\end{array}$ \\
\hline 8 & $\begin{array}{l}\text { San Diego } \\
\text { et al 2016, } \\
\text { UK }^{35}\end{array}$ & $\begin{array}{l}\text { HapTEL } \\
\text { system }\end{array}$ & $\begin{array}{l}\text { (120) 1st } \\
\text { year DS }\end{array}$ & CST & $\begin{array}{l}\text { Carries removal } \\
\text { tasks with increasing } \\
\text { complexity }\end{array}$ & $\begin{array}{l}\text { \% of caries removed; } \\
\text { healthy tissue remain- } \\
\text { ing; pulp exposure, } \\
\text { drilling time }\end{array}$ & $\begin{array}{l}\text { Significant increase in \% } \\
\text { of carries removed, less } \\
\text { pulp exposure, and less } \\
\text { preparation time }\end{array}$ \\
\hline 9 & $\begin{array}{l}\text { de Boer } \\
\text { et al 2016, } \\
\text { Netherlands }^{36}\end{array}$ & $\begin{array}{l}\text { Simodont } \\
\text { Haptic dental } \\
\text { trainer }\end{array}$ & $\begin{array}{l}(124) 1 \text { st } \\
\text { year DS }\end{array}$ & $\mathrm{CCO}$ & $\begin{array}{l}\text { - Cross-figure prepara- } \\
\text { tion Manual dexterity } \\
\text { exercise with 2D or } \\
\text { 3D vision } \\
\text { - Questionnaire }\end{array}$ & Rate of success & $\begin{array}{l}\text { 3D vision achieved } \\
\text { significantly better } \\
\text { results than 2D. } \\
\text { Over } 90 \% \text { preferred } \\
\text { 3D vision }\end{array}$ \\
\hline 10 & $\begin{array}{l}\text { Tubelo et al } \\
\text { 2016, Brazil }\end{array}$ & $\begin{array}{l}\text { Virtual learn- } \\
\text { ing object } \\
\text { (VLO) }\end{array}$ & $\begin{array}{l}\text { (46) 1st year } \\
\text { DS }\end{array}$ & $\mathrm{RCT}$ & $\begin{array}{l}\text { Theoretical knowledge } \\
\text { and skill practice of zinc } \\
\text { phosphate cement }\end{array}$ & $\begin{array}{l}\text { Zinc phosphate } \\
\text { cement manipulation } \\
\text { after immediate or } \\
\text { longitudinal access to } \\
\text { VLO }\end{array}$ & $\begin{array}{l}\text { - VLO showed } \\
\text { significantly higher } \\
\text { results in theoret- } \\
\text { ical post-tests and } \\
\text { better mechanical } \\
\text { properties }\end{array}$ \\
\hline
\end{tabular}


Table 1 (Continued)

\begin{tabular}{|c|c|c|c|c|c|c|c|}
\hline $\begin{array}{l}\text { S. } \\
\text { no }\end{array}$ & $\begin{array}{l}\text { Author, Year, } \\
\text { Country }\end{array}$ & VR system & Participants & $\begin{array}{l}\text { Study } \\
\text { design }\end{array}$ & Tool of assessment & Tested outcome & Results \\
\hline 11 & $\begin{array}{l}\text { Shahriari-Rad } \\
\text { et al } 2017, \\
\text { UK }^{37}\end{array}$ & $\begin{array}{l}\text { hapTEL } \\
\text { virtual dental } \\
\text { workstation }\end{array}$ & $\begin{array}{l}(140) 1 s t \\
\text { year DS }\end{array}$ & $\mathrm{CCT}$ & $\begin{array}{l}\text { - Objective structured } \\
\text { clinical examination } \\
\text { (OSCE) and clinical } \\
\text { skills examination } \\
\text { (CSE) }\end{array}$ & $\begin{array}{l}\text { Students' psychomo- } \\
\text { tor skills and spatial } \\
\text { perceptions }\end{array}$ & $\begin{array}{l}\text { Significant improve- } \\
\text { ment in psychomotor } \\
\text { skills. Combined use of } \\
\text { hapTEL and conven- } \\
\text { tional phantom-head } \\
\text { improved spatial } \\
\text { reasoning, fine motor } \\
\text { skills, hand-eye-finger } \\
\text { coordination and 3D/ } \\
\text { depth perception }\end{array}$ \\
\hline 12 & $\begin{array}{l}\text { Cox et al } \\
2017, \text { UK }^{38}\end{array}$ & $\begin{array}{l}\text { hapTEL } \\
\text { workstations }\end{array}$ & $\begin{array}{l}(138) 1 \mathrm{st} \\
\text { year DS }\end{array}$ & $\mathrm{RCT}$ & $\begin{array}{l}\text { Students' fine } \\
\text { motor-skills }\end{array}$ & $\begin{array}{l}\text { - Hand-eye-finger } \\
\text { movements (pre-, } \\
\text { post-) } \\
\text { - \% of caries } \\
\text { removed, pulp } \\
\text { exposure, and time } \\
\text { - Micro-CT scanning } \\
\text { of excavated plastic } \\
\text { teeth }\end{array}$ & $\begin{array}{l}\text { - Significant correla- } \\
\text { tion between the } \\
\text { pre- and post-test } \\
\text { results, and time } \\
\text { with caries removal } \\
\% \text { and negatively } \\
\text { with pulp exposure. } \\
\text { Roughness of the } \\
\text { preparations varied } \\
\text { amongst students }\end{array}$ \\
\hline 13 & $\begin{array}{l}\text { Al-Saud et al } \\
2017, \text { UK }^{12}\end{array}$ & $\begin{array}{l}\text { Simodont VR } \\
\text { haptic dental } \\
\text { simulator }\end{array}$ & $\begin{array}{l}\text { (63) } \\
\text { Participants } \\
\text { with no pre- } \\
\text { vious dental } \\
\text { experience }\end{array}$ & $\mathrm{RCT}$ & $\begin{array}{l}\text { Preparation of geomet- } \\
\text { ric shapes with device } \\
\text { feedback, or instructor } \\
\text { feedback or both (IDFB) }\end{array}$ & $\begin{array}{l}\text { - Acceptable target } \\
\text { removal percentage } \\
\text { of all tasks was 70\% }\end{array}$ & $\begin{array}{l}\text { Significant differences } \\
\text { between groups in } \\
\text { overall performance, } \\
\text { with IDFB group } \\
\text { substantially better in } \\
\text { performance and fewer } \\
\text { errors }\end{array}$ \\
\hline 14 & $\begin{array}{l}\text { de Boer } \\
\text { et al 2017, } \\
\text { Netherlands }{ }^{23}\end{array}$ & $\begin{array}{l}\text { Simodont } \\
\text { dental } \\
\text { trainer }\end{array}$ & $\begin{array}{l}\text { (101) 1st } \\
\text { year DS }\end{array}$ & $\mathrm{CCO}$ & $\begin{array}{l}\text { Geometric cross prepa- } \\
\text { ration with or without } \\
\text { force feedback (FFB) } \\
\text { - Questionnaire }\end{array}$ & $\begin{array}{l}\text { Success if } 90 \% \text { of } \\
\text { the red target area } \\
\text { removed }\end{array}$ & $\begin{array}{l}\text { Only students with } \\
\text { FFB were able to pass } \\
\text { the tests. } 100 \% \text { of the } \\
\text { students preferred } \\
\text { working with FFB }\end{array}$ \\
\hline 15 & $\begin{array}{l}\text { Gottlieb et al } \\
\text { 2017, United } \\
\text { States }^{41}\end{array}$ & $\begin{array}{l}\text { VR Advanced } \\
\text { simulation }\end{array}$ & $\begin{array}{l}\text { (282) DS } \\
\text { of three } \\
\text { sequential } \\
\text { dental classes }\end{array}$ & CT & $\begin{array}{l}\text { Class I and II amalgam } \\
\text { preparations and resto- } \\
\text { ration, and Class III } \\
\text { and IV composite } \\
\text { restoration }\end{array}$ & $\begin{array}{l}\text { Advanced simulation } \\
\text { exams scores in opera- } \\
\text { tive dentistry and fixed } \\
\text { prosthodontics }\end{array}$ & $\begin{array}{l}\text { Advanced simulation } \\
\text { exam scores } 1 \text { and } \\
2 \text { were predictors of } \\
\text { performance in the } \\
\text { two preclinical courses } \\
\text { based on final course } \\
\text { grades }\end{array}$ \\
\hline 16 & $\begin{array}{l}\text { Ria et al 2018, } \\
\text { UK }{ }^{24}\end{array}$ & $\begin{array}{l}\text { hapTEL } \\
\text { system }\end{array}$ & $\begin{array}{l}\text { (39) 1st year } \\
\text { DS }\end{array}$ & CST & $\begin{array}{l}\text { Cavity preparation } \\
\text { and caries removal of } \\
\text { increasing difficulty }\end{array}$ & $\begin{array}{l}\% \text { of tissue removed, } \\
\text { pulp exposure, time }\end{array}$ & $\begin{array}{l}\text { Insignificant better } \\
\text { performance with the } \\
\text { hapTEL system, despite } \\
\text { lower scores reported } \\
\text { with increased } \\
\text { difficulty }\end{array}$ \\
\hline 17 & $\begin{array}{l}\text { Mirghani et al } \\
\text { 2018, UK }{ }^{26}\end{array}$ & $\begin{array}{l}\text { Simodont } \\
\text { system }\end{array}$ & $\begin{array}{l}\text { (289) Dental } \\
\text { students }\end{array}$ & CCS & $\begin{array}{l}\text { Six manual dexterity } \\
\text { exercises, to remove a } \\
\text { target "red zone" }\end{array}$ & $\begin{array}{l}\text { - \% score of task } \\
\text { completion } \\
\text { - Drill time } \\
\text { (in seconds) }\end{array}$ & $\begin{array}{l}\text { Significant difference in } \\
\text { performance between } \\
\text { year } 1 \text { and years } 4 \text { and } \\
5 . \text { Year } 3 \text { was signif- } \\
\text { icantly different to } \\
\text { year } 5\end{array}$ \\
\hline 18 & $\begin{array}{l}\text { Dwisaptarini } \\
\text { et al } 2018 \text {, } \\
\text { Thailand }^{25}\end{array}$ & $\begin{array}{l}\text { Visuo-tactile } \\
\text { virtual reality } \\
\text { simulator } \\
\text { connected to } \\
\text { two haptic } \\
\text { devices }\end{array}$ & $\begin{array}{l}\text { (32) 6th year } \\
\text { DS }\end{array}$ & $\mathrm{RCT}$ & $\begin{array}{l}\text { Pre- and post-training } \\
\text { clinical assessment } \\
\text { of carries removal on } \\
\text { extracted tooth }\end{array}$ & $\begin{array}{l}\text { - Performance } \\
\text { scores } \\
\text { - Tooth mass loss and } \\
\text { task completion } \\
\text { time }\end{array}$ & $\begin{array}{l}\text { - Post-training perfor- } \\
\text { mance significantly } \\
\text { improved for both } \\
\text { groups with insig- } \\
\text { nificant differences } \\
\text { between groups }\end{array}$ \\
\hline
\end{tabular}


Table 1 (Continued)

\begin{tabular}{|c|c|c|c|c|c|c|c|}
\hline $\begin{array}{l}\text { S. } \\
\text { no }\end{array}$ & $\begin{array}{l}\text { Author, Year, } \\
\text { Country }\end{array}$ & VR system & Participants & $\begin{array}{l}\text { Study } \\
\text { design }\end{array}$ & Tool of assessment & Tested outcome & Results \\
\hline 19 & $\begin{array}{l}\text { Llena el al. } \\
\text { 2018, Spain }{ }^{13}\end{array}$ & $\begin{array}{l}\text { AR cavity } \\
\text { models on } \\
\text { computers } \\
\text { and } \\
\text { mobile } \\
\text { devices }\end{array}$ & $\begin{array}{l}\text { (43) 3rd year } \\
\text { DS }\end{array}$ & $\mathrm{RCT}$ & $\begin{array}{l}\text { - Theoretical } \\
\text { knowledge before, } \\
\text { immediately and } 6 \\
\text { mo after training } \\
\text { - Clinical skills } \\
\text { - Satisfaction } \\
\text { questionnaire }\end{array}$ & $\begin{array}{l}\text { - } 10 \text { theoretical } \\
\text { concepts } \\
\text { - Class I and Class II } \\
\text { cavity preparation } \\
\text { - Students' } \\
\text { satisfaction }\end{array}$ & $\begin{array}{l}\text { Insignificant differences } \\
\text { in knowledge between } \\
\text { groups but signifi- } \\
\text { cant in cavity depth } \\
\text { and extent for Class } \\
\text { I and Class II cavities. } \\
\text { Students preferred } \\
\text { computers over mobile } \\
\text { devices }\end{array}$ \\
\hline 20 & $\begin{array}{l}\text { de Boer } \\
\text { et al 2019, } \\
\text { Netherlands }\end{array}$ & $\begin{array}{l}\text { Simodont } \\
\text { haptic dental } \\
\text { trainer }\end{array}$ & $\begin{array}{l}(126) 1 \mathrm{st} \\
\text { year DS }\end{array}$ & CST & $\begin{array}{l}\text { - Successful drilling } \\
\text { with alternating FFB } \\
\text { - Post assessment } \\
\text { questionnaire }\end{array}$ & $\begin{array}{l}\text { - A preparation } \\
\text { on one block } \\
\text { cross-figure } \\
\text { - Participants' } \\
\text { perception of the } \\
\text { study }\end{array}$ & $\begin{array}{l}83 \% \text { of the students } \\
\text { passed the test. Skill } \\
\text { transfer from one level } \\
\text { of FFB to another was } \\
\text { feasible with sufficient } \\
\text { training }\end{array}$ \\
\hline 21 & $\begin{array}{l}\text { Vincent } \\
\text { et al } 2020 \text {, } \\
\text { France }^{28}\end{array}$ & $\begin{array}{l}\text { haptic } \\
\text { simulator } \\
\text { (Virteasy) }\end{array}$ & $\begin{array}{l}\text { (88) 1st year } \\
\text { DS }\end{array}$ & $\mathrm{RCT}$ & $\begin{array}{l}\text { Both groups took final } \\
\text { exam on plastic ana- } \\
\text { logue teeth }\end{array}$ & Cavity preparation & $\begin{array}{l}\text { Improvement in the } \\
\text { drilling skill of both } \\
\text { groups with insignifi- } \\
\text { cant differences }\end{array}$ \\
\hline 22 & $\begin{array}{l}\text { Murbay et al } \\
\text { 2020, Hong } \\
\text { Kong }^{29}\end{array}$ & $\begin{array}{l}\text { VR-based } \\
\text { system } \\
\text { (Moog } \\
\text { Simodont) }\end{array}$ & $\begin{array}{l}\text { (32) 2nd year } \\
\text { DS }\end{array}$ & $\mathrm{RCT}$ & $\begin{array}{l}\text { Cavity preparation eval- } \\
\text { uation based on SISTA } \\
\text { classification }\end{array}$ & $\begin{array}{l}\text { Prepared cavity depth } \\
\text { and width, and mar- } \\
\text { ginal ridge integrity }\end{array}$ & $\begin{array}{l}\text { Satisfactory domains } \\
\text { were significantly } \\
\text { higher in experimen- } \\
\text { tal group and no } \\
\text { significant difference } \\
\text { between the manual } \\
\text { and digital methods of } \\
\text { evaluation }\end{array}$ \\
\hline 23 & $\begin{array}{l}\text { Osnes et al } \\
2021, \text { UK }^{30}\end{array}$ & $\begin{array}{l}\text { Simodent, } \\
\text { HT for } \\
\text { removal of } \\
\text { carries }\end{array}$ & $\begin{array}{l}\text { (111) 1st } \\
\text { year DS and } \\
17 \text { clinical } \\
\text { practitioners }\end{array}$ & CST & $\begin{array}{l}\text { Removal of virtual cari- } \\
\text { ous lesion spreading } \\
\text { along the amelodentinal } \\
\text { junction (ADJ) }\end{array}$ & Precision score & $\begin{array}{l}\text { Clinicians were } \\
\text { significantly more } \\
\text { precise than students } \\
\text { in removing caries } \\
\text { without excessively } \\
\text { removing the noncari- } \\
\text { ous areas }\end{array}$ \\
\hline
\end{tabular}

Abbreviations: AR, augmented reality; CCO, comparative crossover; CCT, case control trial; CS, cohort study; CST, cross sectional trial; DS, dental students; FFB, force feedback; RCT, randomized controlled trial; VR, virtual reality.

This systematic review showed that VR significantly enhanced the acquisition of dental manual skills even in short periods of training and, to a lesser extent, retention of theoretical knowledge. Despite the fact that few studies reported longer periods of follow-up and reported insignificant differences between virtual and traditional groups. ${ }^{39,48,49,74}$

The diversity in students' learning styles and motivation is the crucial challenge which course designers face. The introduction of virtual simulators in the dental curriculum and the utilization of its data to stratify dental students and predict their clinical performance would provide the opportunity to tailor the learning process to meet individual diversity in students' expertise and allow students to work at their own pace. In this context, the dental curriculum could provide an education that leads to the optimal performance of each student. ${ }^{26}$

Based on the results of this review, five broad, interrelated areas of significance arose; first, the versatility of VR applications and the increased application in some dental disciplines over others; second, HT and its wide use in dental education; third, the development of virtual dental patients to enhance dental education; fourth, the value of digital real-time feedback; and fifth, the access of students to the virtual technology.

First, VR applied in dental education showed a wide range of devices and applied technologies ranging from VR simulation with or without immersive environment, haptic simulators with or without force feedback, AR devices, real-time digital mapping and evaluation, virtual mobile platforms, video games, and other forms of virtual packages. The diversity of the individualized detailed features reflects the fact that there are no well-known educational standards for dental simulators or associated exercises. Additionally, it is doubtful how the variable reliability of the simulator systems may affect dental education outcomes. ${ }^{6}$ Taking into consideration the complexity of the required dental training to reach a high degree of clinical competence, most of the studies included in this review applied VR in restorative dentistry, prosthodontics, and oral and maxillofacial surgery. In contrast, few studies represented pediatric dentistry, dental radiology, periodontology, and orthodontics. Restorative dental tasks might offer the feasibility of customization of 
Table 2 Characteristics of the selected studies in endodontics

\begin{tabular}{|c|c|c|c|c|c|c|c|}
\hline $\begin{array}{l}\text { S. } \\
\text { no }\end{array}$ & $\begin{array}{l}\text { Author, Year, } \\
\text { Country }\end{array}$ & VR system & Participants & $\begin{array}{l}\text { Study } \\
\text { design }\end{array}$ & Assessment tool & Tested outcome & Results \\
\hline 1 & $\begin{array}{l}\text { Pohlenz } \\
\text { et al } 2010 \text {, } \\
\text { Germany }{ }^{15}\end{array}$ & $\begin{array}{l}\text { Medified } \\
\text { Voxel-Mann } \\
\text { virtual } \\
\text { simulator } \\
\text { with haptic } \\
\text { feedback }\end{array}$ & $\begin{array}{l}\text { (53) DS of dif- } \\
\text { ferent years }\end{array}$ & CST & $\begin{array}{l}\text { Students performed } \\
\text { virtual apicectomies } \\
\text { and responded to a } \\
\text { questionnaire }\end{array}$ & $\begin{array}{l}1-5 \text { scale to detect } \\
\text { simulator is useful, } \\
\text { realistic, sufficient, } \\
\text { and desirable }\end{array}$ & $\begin{array}{l}\text { The students } \\
\text { indicated that } \\
\text { FFB, spatial 3D } \\
\text { perception, and } \\
\text { image resolution } \\
\text { of the simulator } \\
\text { were sufficient }\end{array}$ \\
\hline 2 & $\begin{array}{l}\text { Suebnukarn } \\
\text { et al } 2010 \text {, } \\
\text { Thailand }^{43}\end{array}$ & $\begin{array}{l}\text { VR haptic } \\
\text { simula- } \\
\text { tor with } \\
\text { augmented } \\
\text { kinematic } \\
\text { feedback }\end{array}$ & $\begin{array}{l}\text { (32) 4th year } \\
\text { DS }\end{array}$ & RCT & $\begin{array}{l}\text { Virtual access cavity } \\
\text { preparation in upper } \\
\text { 1st molar (Three groups } \\
\text { received kinematic } \\
\text { augmented feedback } \\
\text { and one control group } \\
\text { did not) }\end{array}$ & Performance scores & $\begin{array}{l}\text { The three } \\
\text { kinematic } \\
\text { feedback groups } \\
\text { significantly } \\
\text { scored higher } \\
\text { with no signifi- } \\
\text { cant difference in } \\
\text { between }\end{array}$ \\
\hline 3 & $\begin{array}{l}\text { Suebnukarn } \\
\text { et al } 2011 \text {, } \\
\text { Thailand } 44\end{array}$ & $\begin{array}{l}\text { VR haptic } \\
\text { simulator }\end{array}$ & $\begin{array}{l}\text { (32) 4th year } \\
\text { DS }\end{array}$ & RCT & $\begin{array}{l}\text { Access cavity preparation } \\
\text { was assessed before and } \\
\text { after training for both } \\
\text { groups on an extracted } \\
\text { tooth }\end{array}$ & $\begin{array}{l}\text { Procedural errors } \\
\text { assessed by an } \\
\text { expert }\end{array}$ & $\begin{array}{l}\text { Post training error } \\
\text { scores improved } \\
\text { significantly for } \\
\text { both groups. } \\
\text { Hard tissue loss } \\
\text { was significantly } \\
\text { less in the haptic } \\
\text { group, but not } \\
\text { time }\end{array}$ \\
\hline 4 & $\begin{array}{l}\text { Suebnukarn } \\
\text { et al 2012, } \\
\text { Thailand }{ }^{14}\end{array}$ & $\begin{array}{l}\text { VR haptic } \\
\text { simulator }\end{array}$ & $\begin{array}{l}\text { (10) Post grad- } \\
\text { uate endodon- } \\
\text { tic trainees }\end{array}$ & RCT & $\begin{array}{l}\text { Endodontic microsurgery } \\
\text { of apicectomy }\end{array}$ & $\begin{array}{l}\text { Endodontic compe- } \\
\text { tency scale by two } \\
\text { experts }\end{array}$ & $\begin{array}{l}\text { Significant higher } \\
\text { scores of trials } \\
\text { performed after } \\
\text { virtual presurgical } \\
\text { training }\end{array}$ \\
\hline 5 & $\begin{array}{l}\text { Wang et al } \\
\text { 2015, China }{ }^{45}\end{array}$ & $\begin{array}{l}\text { iDental surgi- } \\
\text { cal simulator } \\
\text { with a haptic } \\
\text { device }\end{array}$ & $\begin{array}{l}\text { (10) Fresh- } \\
\text { graduate DS, } \\
\text { (10) Residents }\end{array}$ & CST & $\begin{array}{l}\text { - Two dental drill- } \\
\text { ing tasks:1-carries } \\
\text { removal, 2- pulp } \\
\text { chamber opening } \\
\text { - Subjective evaluation } \\
\text { questionnaire }\end{array}$ & $\begin{array}{l}\text { - Time and } \\
\text { amount of } \\
\text { tissue removed }\end{array}$ & $\begin{array}{l}\text { Insignificant dif- } \\
\text { ferences between } \\
\text { groups, though } \\
\text { the residents } \\
\text { spent more time. } \\
\text { Dentists' showed } \\
\text { positive attitudes } \\
\text { toward the } \\
\text { system }\end{array}$ \\
\hline 6 & $\begin{array}{l}\text { Reymus } \\
\text { et al } 2020 \text {, } \\
\text { Germany }{ }^{46}\end{array}$ & $\begin{array}{l}\text { VR } \\
\text { environment }\end{array}$ & $\begin{array}{l}\text { (32) 3rd year } \\
\text { DS }\end{array}$ & CST & $\begin{array}{l}\text { Root canal anatomy } \\
\text { studies on periapical } \\
\text { radiographs, CBCT } \\
\text { scan and virtual reality } \\
\text { environment }\end{array}$ & $\begin{array}{l}\text { Post training } \\
\text { knowledge } \\
\text { questionnaire }\end{array}$ & $\begin{array}{l}\text { CBCT or VR had } \\
\text { significant better } \\
\text { results than peri- } \\
\text { apical radiograph. } \\
\text { Most students' } \\
\text { preferred method } \\
\text { of studying } \\
\text { dental anatomy } \\
\text { was VR }\end{array}$ \\
\hline
\end{tabular}

Abbreviations: CBCT, cone beam computerized tomography; CST, cross sectional trial; DS, dental students; FFB, force feedback; RCT, randomized controlled trial; VR, virtual reality.

the required assignments, whereas other dental disciplines may require higher customization and knowledge to fulfill specific field's requirements. ${ }^{90}$

Second, this review showed that HT was the most used technology, especially in tasks that require drilling and tooth preparations, which agree with Towers et al. ${ }^{6}$ HT offers an additional dimension to VR through the sense of touch and force feedback (FFB) of the different tooth-layered structure and bone. Thus, HT proved efficient in training junior dental students the hand-eye coordination and spatial reasoning skills. It also helped students improve the preparation accuracy, shortened the preparation time in the very early stages of training, and augmented a conservative preparation approach..$^{15,22,37,68}$ However, due to the unique character of dental procedures, FFB should be improved and included as an integral feature in any educational dental simulator to enhance the perception of the tooth structure and different layers of bone. Training with FFB provides a sense of realism and allows the learner to obtain the feel of an invasive procedure in a virtual learning environment. ${ }^{23,27}$

Third, VP showed wide applications in dental education and had a significant positive impact on manual skills and 
Table 3 Characteristics of the selected studies in maxillofacial surgery and oral pain

\begin{tabular}{|c|c|c|c|c|c|c|c|}
\hline $\begin{array}{l}\text { S. } \\
\text { no }\end{array}$ & $\begin{array}{l}\text { Author, } \\
\text { Year, } \\
\text { Country }\end{array}$ & VR system & Participants & $\begin{array}{l}\text { Study } \\
\text { design }\end{array}$ & Tool of assessment & Tested outcome & Results \\
\hline 1 & $\begin{array}{l}\text { Clark } \\
\text { et al } 2012 \text {, } \\
\text { United } \\
\text { States }^{47}\end{array}$ & $\begin{array}{l}\text { Autonomous } \\
\text { virtual patient } \\
(\mathrm{AVP})\end{array}$ & $\begin{array}{l}\text { (26) 4th year } \\
\text { DS, } \\
\text { (10) board } \\
\text { experts }\end{array}$ & $\mathrm{CT}$ & $\begin{array}{l}\text { Examination of four VP } \\
\text { with orofacial pain or oral } \\
\text { medicine problem }\end{array}$ & $\begin{array}{l}\text { Examination time, number } \\
\text { of diagnostic tests, num- } \\
\text { ber of medications }\end{array}$ & $\begin{array}{l}\text { Significant differences } \\
\text { in the final total score, } \\
\text { the number of diag- } \\
\text { nostic tests ordered, } \\
\text { and the number of } \\
\text { medications selected }\end{array}$ \\
\hline 2 & $\begin{array}{l}\text { Pulijala } \\
\text { et al } 2018 \text {, } \\
\text { India }{ }^{54}\end{array}$ & $\begin{array}{l}\text { IVR surgery } \\
\text { to train } \\
\text { Le Fort-1 } \\
\text { surgery }\end{array}$ & $\begin{array}{l}\text { (95) Surgical } \\
\text { residents }\end{array}$ & $\mathrm{RCT}$ & $\begin{array}{l}\text { 1. Pre- and post-training } \\
\text { self-assessment of per- } \\
\text { ceived confidence } \\
2 \text {. Objective cognitive } \\
\text { skills assessment }\end{array}$ & $\begin{array}{l}\text { 1. Self-confidence } \\
\text { 2. Change in knowl- } \\
\text { edge of surgical } \\
\text { residents }\end{array}$ & $\begin{array}{l}\text { Study group showed } \\
\text { significantly greater } \\
\text { perceived self-con- } \\
\text { fidence but insignif- } \\
\text { icant differences in } \\
\text { knowledge scores }\end{array}$ \\
\hline 3 & $\begin{array}{l}\text { Seifert } \\
\text { et al } 2019 \text {, } \\
\text { Germany }^{48}\end{array}$ & $\begin{array}{l}\text { VP on } \\
\text { e-learning } \\
\text { platform } \\
\text { "Lernbar" }\end{array}$ & $\begin{array}{l}\text { (57) 4th year } \\
\text { DS }\end{array}$ & $\mathrm{RCT}$ & $\begin{array}{l}\text { - Theoretical tests; pre, } \\
\text { immediately after T1, } \\
\text { and 6-wk T2 } \\
\text { - Self-assessment } \\
\text { questionnaire }\end{array}$ & $\begin{array}{l}\text { - MCQs for structured } \\
\text { facial examination and } \\
\text { placing a venous cath- } \\
\text { eter and Ernst ligature } \\
\text { - Self-assessment } \\
\text { of knowledge and } \\
\text { competency }\end{array}$ & $\begin{array}{l}\text { VP group scored } \\
\text { better than control } \\
\text { group at T1 and no } \\
\text { difference at T2. Both } \\
\text { interventions led to } \\
\text { a significant growth } \\
\text { in self-assessed } \\
\text { competence }\end{array}$ \\
\hline 4 & $\begin{array}{l}\text { Mladenovic } \\
\text { et al } 2019 \text {, } \\
\text { Serbia }{ }^{51}\end{array}$ & $\begin{array}{l}\text { AR simulator } \\
\text { on mobiles }\end{array}$ & $\begin{array}{l}\text { (41) } 4 \text { th and } \\
5 \text { th year DS }\end{array}$ & $\mathrm{RCT}$ & $\begin{array}{l}\text { Application of local } \\
\text { anesthesia } \\
\text { Post-clinical knowledge } \\
\text { questionnaire }\end{array}$ & $\begin{array}{l}\text { - Knowledge and skills. } \\
\text { - Measurement of heart- } \\
\text { beat during anesthesia } \\
\text { administration }\end{array}$ & $\begin{array}{l}\text { The experimental } \\
\text { group had higher } \\
\text { average score, less } \\
\text { time of administra- } \\
\text { tion, and higher suc- } \\
\text { cess rate. Both groups } \\
\text { had a statistically } \\
\text { significant increase in } \\
\text { heart rate }\end{array}$ \\
\hline 5 & $\begin{array}{l}\text { Mardani } \\
\text { et al } 2020 \text {, } \\
\text { Iran }^{49}\end{array}$ & $\begin{array}{l}\text { Web-based } \\
\text { VP in clin- } \\
\text { ical deci- } \\
\text { sion-making } \\
\text { ability }\end{array}$ & (76) DS & $\begin{array}{l}\text { Quasi } \\
\text { experi- } \\
\text { ment }\end{array}$ & $\begin{array}{l}\text { Knowledge pre-, post- } \\
\text { (1 wk), and post-training } \\
\text { ( } 1 \text { mo }) \\
\text { - Questionnaire on pro- } \\
\text { cedural knowledge }\end{array}$ & $\begin{array}{l}\text { Procedural knowledge } \\
\text { Problem-solving ability }\end{array}$ & $\begin{array}{l}\text { Clinical decision-mak- } \\
\text { ing score of VP group } \\
\text { was significant more } \\
\text { than the control group } \\
\text { in post-test } 1 \text { but con- } \\
\text { trol group scores rose } \\
\text { significantly more in } \\
\text { post-test } 2\end{array}$ \\
\hline 7 & $\begin{array}{l}\text { Mladenovic } \\
\text { et al } 2020 \text {, } \\
\text { Serbia }^{52}\end{array}$ & $\begin{array}{l}\text { Mobile AR } \\
\text { simulator }\end{array}$ & $\begin{array}{l}\text { (11) 4th year } \\
\text { DS }\end{array}$ & CST & $\begin{array}{l}\text { Simulated local anesthesia } \\
\text { (infiltrations and nerve } \\
\text { block) then electronic } \\
\text { satisfaction survey }\end{array}$ & Student satisfaction & $\begin{array}{l}\text { All respondents } \\
\text { (100\%) believe (agree } \\
\text { and strongly agree) } \\
\text { that the application } \\
\text { helped them to } \\
\text { better understand the } \\
\text { techniques of local } \\
\text { anesthesia }\end{array}$ \\
\hline 6 & $\begin{array}{l}\text { Sakowitz } \\
\text { et al } 2020 \text {, } \\
\text { United } \\
\text { States }^{53}\end{array}$ & $\begin{array}{l}\text { VP of } \\
\text { complex } \\
\text { orthognathic } \\
\text { cases }\end{array}$ & $\begin{array}{l}\text { (30) 3rd year } \\
\text { DS }\end{array}$ & $\mathrm{RCT}$ & $\begin{array}{l}\text { - Knowledge pre- (T0), } \\
\text { post- (T1), and fol- } \\
\text { low-up test (T2) } \\
\text { - Written case analysis of } \\
\text { two cases }\end{array}$ & $\begin{array}{l}\text { - MCQs score } \\
\text { - Case analysis score }\end{array}$ & $\begin{array}{l}\text { No significant } \\
\text { difference between } \\
\text { the groups in MCQs } \\
\text { examinations and the } \\
\text { written case analysis }\end{array}$ \\
\hline 8 & $\begin{array}{l}\text { Collaço } \\
\text { et al } 2020 \text {, } \\
\text { Brazil }^{55}\end{array}$ & $\begin{array}{l}\text { IVR in inferior } \\
\text { alveolar } \\
\text { nerve block } \\
\text { anesthesia }\end{array}$ & (163) DS & $\mathrm{CT}$ & $\begin{array}{l}\text { - Technical skills } \\
\text { - Participants' subjec- } \\
\text { tive experience with } \\
\text { syringe handling and } \\
\text { simulator sickness }\end{array}$ & $\begin{array}{l}\text { Task execution } \\
\text { time, insertion accuracy, } \\
\text { insertion point coordi- } \\
\text { nates, needle angle, } \\
\text { and needle depth }\end{array}$ & $\begin{array}{l}\text { IVRs were significantly } \\
\text { more accurate and } \\
\text { confident and took } \\
\text { less time. No signif- } \\
\text { icant differences in } \\
\text { needle angle and nee- } \\
\text { dle depth. Participants } \\
\text { perceived a high sense } \\
\text { of realism with the } \\
\text { haptic feedback when } \\
\text { handling the syringe }\end{array}$ \\
\hline
\end{tabular}


Table 3 (Continued)

\begin{tabular}{|l|l|l|l|l|l|l|l|}
\hline $\begin{array}{l}\text { S. } \\
\text { no }\end{array}$ & $\begin{array}{l}\text { Author, } \\
\text { Year, } \\
\text { Country }\end{array}$ & VR system & Participants & $\begin{array}{l}\text { Study } \\
\text { design }\end{array}$ & Tool of assessment & Tested outcome & Results \\
\hline 9 & $\begin{array}{l}\text { McAlpin } \\
\text { et al 2020, } \\
\text { United } \\
\text { States }\end{array}$ & $\begin{array}{l}\text { Web-based } \\
\text { patient } \\
\text { simulator } \\
\text { (Web-Sim) }\end{array}$ & (221) DS & RCT & $\begin{array}{l}\text { Cognitive, psychomo- } \\
\text { tor, and professional } \\
\text { interpersonal skills in local } \\
\text { anesthesia and nonsurgi- } \\
\text { cal extraction }\end{array}$ & $\begin{array}{l}\text { Student-recorded } \\
\text { role-paly video } \\
\text { MCQs }\end{array}$ & $\begin{array}{l}\text { Web-Sim group } \\
\text { scored significantly } \\
\text { higher in the role-play } \\
\text { videos but insignifi- } \\
\text { cant MCQs scores }\end{array}$ \\
\hline
\end{tabular}

Abbreviations: AR, augmented reality; CT, comparative trial; CST, cross sectional trial; IVR, immersive virtual reality; MCQs, multiple choice questions; RCT, randomized controlled trial; VP, virtual patients.

Table 4 Characteristics of the selected studies in prosthodontics

\begin{tabular}{|c|c|c|c|c|c|c|c|}
\hline $\begin{array}{l}\text { S. } \\
\text { no }\end{array}$ & $\begin{array}{l}\text { Author, Year, } \\
\text { Country }\end{array}$ & Technology & Participants & $\begin{array}{l}\text { Study } \\
\text { design }\end{array}$ & Assessment tool & Tested outcome & Results \\
\hline 1 & $\begin{array}{l}\text { Kikuchi et al } \\
\text { 2013, Japan }\end{array}$ & $\begin{array}{l}\text { DentSim, VR } \\
\text { simulation } \\
\text { (VRS) }\end{array}$ & $\begin{array}{l}\text { (43) 5th year } \\
\text { DS }\end{array}$ & RCT & $\begin{array}{l}\text { Porcelain fused to metal } \\
\text { crown preparation }\end{array}$ & $\begin{array}{l}\text { Total scores included } \\
12 \text { preparation items } \\
\text { and time }\end{array}$ & $\begin{array}{l}\text { VRS scores were } \\
\text { significantly higher. } \\
\text { Instructor's feedback } \\
\text { did not result in signif- } \\
\text { icant difference within } \\
\text { VRS groups }\end{array}$ \\
\hline 2 & $\begin{array}{l}\text { Hamil et al } \\
\text { 2014, United } \\
\text { States }^{59}\end{array}$ & $\begin{array}{l}\text { Surface map- } \\
\text { ping tech- } \\
\text { nology E4D } \\
\text { for students' } \\
\text { grading }\end{array}$ & (81) DS & CST & $\begin{array}{l}\text { Students' perception } \\
\text { questionnaire }\end{array}$ & $\begin{array}{l}\text { Students' attitudes on } \\
\text { the effectiveness of } \\
\text { software in developing } \\
\text { clinical skills }\end{array}$ & $\begin{array}{l}\text { Students preferred } \\
\text { digital grading over } \\
\text { traditional and found } \\
\text { the software helping } \\
\text { them to understand } \\
\text { their deficiencies }\end{array}$ \\
\hline 3 & $\begin{array}{l}\text { Eve et al } \\
2014, \text { United } \\
\text { States }^{60}\end{array}$ & $\begin{array}{l}\text { 3D immer- } \\
\text { sive haptic } \\
\text { simulator }\end{array}$ & $\begin{array}{l}\text { (12) novice } \\
\text { DS, (12) } \\
\text { experienced } \\
\text { prosthodontics } \\
\text { residents }\end{array}$ & CT & $\begin{array}{l}\text { Simulated caries removal } \\
\text { exercise }\end{array}$ & $\begin{array}{l}\text { Percentages of carious } \\
\text { lesion removed, and } \\
\text { volume of surrounding } \\
\text { sound tooth structure } \\
\text { removed }\end{array}$ & $\begin{array}{l}\text { Efficiency of carries } \\
\text { removal improved } \\
\text { significantly for both } \\
\text { novice and experienced } \\
\text { subjects }\end{array}$ \\
\hline 4 & $\begin{array}{l}\text { Callan et al } \\
\text { 2014, United } \\
\text { States }^{61}\end{array}$ & $\begin{array}{l}\text { E4D } \\
\text { Laboratory } \\
\text { works virtual } \\
\text { simula- } \\
\text { tion using } \\
\text { CAD/CAM } \\
\text { technology }\end{array}$ & $\begin{array}{l}\text { (76) 2nd year } \\
\text { DS }\end{array}$ & RCT & $\begin{array}{l}\text { - CES within the inter- } \\
\text { vention group (1st } \\
\text { effectiveness analysis) } \\
\text { and between the two } \\
\text { groups (2nd efficacy } \\
\text { analysis) }\end{array}$ & $\begin{array}{l}\text { Full gold crown prepa- } \\
\text { ration on tooth \#30. } \\
\text { Students' scores before } \\
\text { and after using E4D and } \\
\text { using E4D versus not. } \\
\text { Post training and post- } \\
\text { exam survey }\end{array}$ & $\begin{array}{l}\text { 1st effectiveness } \\
\text { analysis showed no } \\
\text { difference in outcomes. } \\
\text { 2nd efficacy analysis } \\
\text { showed insignificant } \\
\text { higher mean compe- } \\
\text { tency scores of CAD/ } \\
\text { CAM group. Students } \\
\text { appreciated the sub- } \\
\text { jectivity of system's } \\
\text { evaluation and the } \\
\text { beneficiary in tooth } \\
\text { surfaces reduction }\end{array}$ \\
\hline 5 & $\begin{array}{l}\text { Lin et al } \\
\text { 2018, United } \\
\text { States }^{56}\end{array}$ & $\begin{array}{l}\text { 3D instruc- } \\
\text { tional } \\
\text { models' appli- } \\
\text { cation on } \\
\text { smartphones }\end{array}$ & $\begin{array}{l}\text { (90) 2nd year } \\
\text { DS }\end{array}$ & CST & $\begin{array}{l}\text { Instruction models on rest } \\
\text { seat preparation then a } \\
\text { questionnaire }\end{array}$ & $\begin{array}{l}\text { Evaluate students' } \\
\text { usage and perceptions } \\
\text { of the digital models }\end{array}$ & $\begin{array}{l}73 \% \text { of the participants } \\
\text { who viewed the models } \\
\text { responded either agree } \\
\text { or strongly agree to the } \\
\text { benefits of the models }\end{array}$ \\
\hline 6 & $\begin{array}{l}\text { Liu et al } 2018, \\
\text { China }^{62}\end{array}$ & $\begin{array}{l}\text { Online } \\
\text { Peer-Review } \\
\text { System } \\
\text { (OPRS) and } \\
\text { Real-time } \\
\text { Dental } \\
\text { Training and } \\
\text { Evaluation } \\
\text { (RDTES) }\end{array}$ & $\begin{array}{l}\text { (66) 4th year } \\
\text { DS }\end{array}$ & RCT & $\begin{array}{l}\text { Post-training prepa- } \\
\text { ration of an anterior } \\
\text { ceramic crown on } \\
\text { phantom model } \\
\text { - Questionnaires }\end{array}$ & $\begin{array}{l}\text { Pre-defined } 15 \\
\text { evaluation criteria of } \\
\text { the ceramic crown } \\
\text { preparation } \\
\text { - Students' attitude }\end{array}$ & $\begin{array}{l}\text { Digital group was } \\
\text { significantly better than } \\
\text { the traditional group } \\
\text { and } 96.97 \% \text { of it agreed } \\
\text { or strongly agreed on } \\
\text { the clinical benefits of } \\
\text { the system }\end{array}$ \\
\hline
\end{tabular}


Table 4 (continued)

\begin{tabular}{|c|c|c|c|c|c|c|c|}
\hline $\begin{array}{l}\text { S. } \\
\text { no }\end{array}$ & $\begin{array}{l}\text { Author, Year, } \\
\text { Country }\end{array}$ & Technology & Participants & $\begin{array}{l}\text { Study } \\
\text { design }\end{array}$ & Assessment tool & Tested outcome & Results \\
\hline 7 & $\begin{array}{l}\text { Kozarovska } \\
\text { and Larsson } \\
2018, \\
\text { Sweden }^{63}\end{array}$ & $\begin{array}{l}\text { Digital } \\
\text { tool for } \\
\text { preparation } \\
\text { Validation } \\
\text { (PVT) }\end{array}$ & $\begin{array}{l}\text { (57) 3rd year } \\
\text { DS }\end{array}$ & $\mathrm{CCO}$ & $\begin{array}{l}\text { All-ceramic crown in ante- } \\
\text { rior teeth } \\
\text { "prep. and scan" or “best } \\
\text { of three” } \\
\text { - Students' question- } \\
\text { naire and teachers' } \\
\text { opinions }\end{array}$ & $\begin{array}{l}\text { The level of agreement } \\
\text { between the students' } \\
\text { self-assessment and } \\
\text { the information from } \\
\text { the PVT }\end{array}$ & $\begin{array}{l}\text { "prep-and- scan" } \\
\text { showed increase } \\
\text { in agreement from } \\
\text { attempt one to three, } \\
\text { with PVT. In "best of } \\
\text { three" lower levels of } \\
\text { agreement. Students } \\
\text { rated PVT positively } \\
\text { and teachers' feedback } \\
\text { suggested improve- } \\
\text { ment modifications }\end{array}$ \\
\hline 8 & $\begin{array}{l}\text { Nagy } \\
\text { et al 2018, } \\
\text { Hungary }\end{array}$ & $\begin{array}{l}\text { Dental } \\
\text { Teacher } \\
\text { software }\end{array}$ & $\begin{array}{l}\text { (36) 4th year } \\
\text { DS }\end{array}$ & RCT & $\begin{array}{l}\text { Ceramic mesio-occluso- } \\
\text { buccal on lay in a plastic } \\
\text { model, scanned and } \\
\text { assessed by Dental } \\
\text { Teacher software }\end{array}$ & $\begin{array}{l}\text { Six cavity evaluation } \\
\text { parameters }\end{array}$ & $\begin{array}{l}\text { Three of the six cavity } \\
\text { dimension parameters } \\
\text { improved significantly } \\
\text { in the test group }\end{array}$ \\
\hline 9 & $\begin{array}{l}\text { Liu et al 2020, } \\
\text { China }^{65}\end{array}$ & $\begin{array}{l}\text { Virtual Real- } \\
\text { time dental } \\
\text { training and } \\
\text { evaluation } \\
\text { System } \\
\text { (RDTES) }\end{array}$ & $\begin{array}{l}\text { (57) 5th year } \\
\text { DS }\end{array}$ & CST & $\begin{array}{l}\text { Ceramic crown } \\
\text { preparation, } \\
\text { pre- and post-learning } \\
\text { assessment } \\
\text { - Questionnaire }\end{array}$ & $\begin{array}{l}\text { Instrument selection, } \\
\text { preparation section, } \\
\text { reduction, surface and } \\
\text { profile }\end{array}$ & $\begin{array}{l}\text { Mean total outcome } \\
\text { score after VR training } \\
\text { was significantly higher } \\
\text { except in mean error } \\
\text { score. } 97 \% \text { agreed or } \\
\text { strongly agreed that } \\
\text { the virtual system } \\
\text { could improve their } \\
\text { practice }\end{array}$ \\
\hline 10 & $\begin{array}{l}\text { Tang } \\
\text { et al 2021, } \\
\text { China }^{66}\end{array}$ & $\begin{array}{l}\text { Digital real- } \\
\text { time evalua- } \\
\text { tion system } \\
\text { (DCARER) }\end{array}$ & $\begin{array}{l}(60) \text { DS, }(73) \\
\text { Prosthodontic } \\
\text { residents, } \\
\text { (10) faculty } \\
\text { members }\end{array}$ & RCT & $\begin{array}{l}\text { - Crown preparation pro- } \\
\text { cess and final scores } \\
\text { - Questionnaire }\end{array}$ & $\begin{array}{l}\text { - Agreement between } \\
\text { DCARER scores and } \\
\text { expert } \\
\text { - Comparison } \\
\text { between groups' } \\
\text { crown preparation } \\
\text { scores }\end{array}$ & $\begin{array}{l}\text { Insignificant differences } \\
\text { between DCARER and } \\
\text { experts' scoring } \\
\text { - Tooth preparation } \\
\text { scores of the tradi- } \\
\text { tional group were } \\
\text { significantly lower. } \\
\text { More students in } \\
\text { the digital group } \\
\text { believed the judg- } \\
\text { ment of DCARER is } \\
\text { more objective }\end{array}$ \\
\hline 11 & $\begin{array}{l}\text { Serrano } \\
\text { et al 2020, } \\
\text { Netherlands }^{3}\end{array}$ & $\begin{array}{l}\text { HT models of } \\
\text { real patients } \\
\text { added in } \\
\text { Simodont }\end{array}$ & $\begin{array}{l}\text { (10) } 4 \text { th and } \\
\text { 5th year DS }\end{array}$ & CST & $\begin{array}{l}\text { Training on real } \\
\text { patient-haptic volumet- } \\
\text { ric models, then in real } \\
\text { patient } \\
\text { Final open answer survey }\end{array}$ & $\begin{array}{l}\text { Perceived learning } \\
\text { value of the technology } \\
\text { and self-assessed confi- } \\
\text { dence and limitations }\end{array}$ & $\begin{array}{l}\text { Identifiable five } \\
\text { dimensions of the main } \\
\text { features of VR: added } \\
\text { value, competence } \\
\text { development, self-ef- } \\
\text { ficacy, outcomes, and } \\
\text { room for development }\end{array}$ \\
\hline 12 & $\begin{array}{l}\text { Mai et al } \\
\text { 2020, Korea }{ }^{57}\end{array}$ & $\begin{array}{l}\text { 3D simulated } \\
\text { graphic } \\
\text { dental } \\
\text { models and } \\
\text { computer } \\
\text { designed } \\
\text { Software }\end{array}$ & $\begin{array}{l}\text { (60) 2nd year } \\
\text { DS }\end{array}$ & $\mathrm{RCT}$ & $\begin{array}{l}\text { After the course, } \\
\text { 1. An attitudinal survey } \\
\text { 2. Final examination }\end{array}$ & $\begin{array}{l}\text { - Assessing the prefer- } \\
\text { ence of participants } \\
\text { - Knowledge test } \\
\text { on the principles } \\
\text { of adjustment of } \\
\text { deflective occlusion }\end{array}$ & $\begin{array}{l}\text { Students' feedback } \\
\text { indicated that the 3D } \\
\text { simulation method was } \\
\text { effective in acquir- } \\
\text { ing knowledge on } \\
\text { occlusion. Examination } \\
\text { scores were signifi- } \\
\text { cantly higher in the 3D } \\
\text { simulation group }\end{array}$ \\
\hline 13 & $\begin{array}{l}\text { Al-Saud et al } \\
\text { 2020, UK }{ }^{67}\end{array}$ & $\begin{array}{l}\text { Simodont } \\
\text { haptic } \\
\text { simulator }\end{array}$ & $\begin{array}{l}\text { (72) 4th year } \\
\text { DS }\end{array}$ & RCS & $\begin{array}{l}\text { Students' scores at year } 2 \\
\text { on traditional training or } \\
\text { haptic VR training }\end{array}$ & $\begin{array}{l}\text { Full crown test prepara- } \\
\text { tion on patient in year } 4\end{array}$ & $\begin{array}{l}\text { VR haptic simulator } \\
\text { assessment score was } \\
\text { a significant predic- } \\
\text { tor of clinical crown } \\
\text { performance }\end{array}$ \\
\hline
\end{tabular}

Abbreviations: CES, competency exam scores; CCO, comparative crossover; CT, comparative trial; CST, cross sectional trial; DS, dental students; RCS, retrospective cohort study; RCT, randomized controlled trial; VR, virtual reality. 
Table 5 Characteristics of the selected studies in implantology

\begin{tabular}{|c|c|c|c|c|c|c|c|}
\hline $\begin{array}{l}\text { S. } \\
\text { no }\end{array}$ & $\begin{array}{l}\text { Author, } \\
\text { Year, } \\
\text { Country }\end{array}$ & VR system & Participants & $\begin{array}{l}\text { Study } \\
\text { design }\end{array}$ & Assessment tool & Tested outcome & Results \\
\hline 1 & $\begin{array}{l}\text { Qi et al } \\
2013 \\
\text { China }^{72}\end{array}$ & $\begin{array}{l}\text { Active and } \\
\text { passive } \\
\text { controlling } \\
\text { 3D virtual } \\
\text { webpages }\end{array}$ & $\begin{array}{l}\text { (95) 1st and 2nd } \\
\text { year } \\
\text { DS }\end{array}$ & RCT & $\begin{array}{l}\text { Post-training assess- } \\
\text { ment of knowledge } \\
\text { on dental implant } \\
\text { restoration }\end{array}$ & $\begin{array}{l}\text { Relative quality of infor- } \\
\text { mation acquisition }\end{array}$ & $\begin{array}{l}\text { Passive 3D control } \\
\text { had significant high } \\
\text { scores, a significant } \\
\text { correlation existed } \\
\text { between the scores } \\
\text { on a mental rotations } \\
\text { test and the subjects' } \\
\text { performance on the } \\
\text { post-test }\end{array}$ \\
\hline 2 & $\begin{array}{l}\text { Joseph et } \\
\text { al } 2014, \\
\text { France }^{68}\end{array}$ & $\begin{array}{l}\text { Virteasy, } \\
\text { haptic den- } \\
\text { tal simulator } \\
\text { (implant } \\
\text { surgery) }\end{array}$ & $\begin{array}{l}\text { (40) 3rd year DS, } \\
\text { (20) Experienced } \\
\text { practitioners }\end{array}$ & RCT & $\begin{array}{l}\text { Implant drilling in } \\
\text { the } 1 \text { st molar region } \\
\text { in a custom-made } \\
\text { mandibular resin } \\
\text { model }\end{array}$ & $\begin{array}{l}\text { Accuracy of implant } \\
\text { placement and drilling } \\
\text { times }\end{array}$ & $\begin{array}{l}\text { The results of the } \\
\text { simulator group were } \\
\text { significantly close } \\
\text { to the experienced } \\
\text { operators }\end{array}$ \\
\hline 3 & $\begin{array}{l}\text { Golob } \\
\text { Deeb et } \\
\text { al } 2019, \\
\text { United } \\
\text { States }^{69}\end{array}$ & $\begin{array}{l}\text { Dynamic } \\
\text { guidance } \\
\text { system } \\
\text { software for } \\
\text { virtual } \\
\text { implant } \\
\text { placement }\end{array}$ & $\begin{array}{l}\text { (14) Predoctoral } \\
\text { students }\end{array}$ & CST & $\begin{array}{l}\text { Five implant place- } \\
\text { ments ( } 3 \text { maxillary } \\
\text { or } 4 \text { mandibular) } \\
\text { positions }\end{array}$ & $\begin{array}{l}\text { Surgical time horizontal, } \\
\text { vertical, and angulation } \\
\text { discrepancies }\end{array}$ & $\begin{array}{l}\text { Significant reduction } \\
\text { in time from 1st to } \\
\text { 2nd trial, then pla- } \\
\text { teaued. 3D angulation } \\
\text { and 2D vertical apex } \\
\text { deviation improved } \\
\text { with each attempt, } \\
\text { but changes in lateral } \\
\text { 2D and overall 3D } \\
\text { apex deviations were } \\
\text { not significant }\end{array}$ \\
\hline 4 & $\begin{array}{l}\text { Zhang et } \\
\text { al } 2020 \text {, } \\
\text { China }^{70}\end{array}$ & $\begin{array}{l}\text { VR sim- } \\
\text { ulation } \\
\text { platform }\end{array}$ & $\begin{array}{l}(166) 2^{\text {nd }} \text { and } 3^{\text {rd }} \\
\text { year DS }\end{array}$ & RCT & $\begin{array}{l}\text { - Pre- and } \\
\text { post-theoretical } \\
\text { test, subjec- } \\
\text { tive evaluation } \\
\text { of operation } \\
\text { procedures, } \\
\text { implant accuracy } \\
\text { in CBCT, and } \\
\text { questionnaire }\end{array}$ & $\begin{array}{l}\text { - Procedural accu- } \\
\text { racy vs. jaw-bone } \\
\text { simulation } \\
\text { - Degree of satisfaction }\end{array}$ & $\begin{array}{l}\text { VR combined with } \\
\text { jawbone groups had } \\
\text { significantly higher } \\
\text { increase in scores } \\
\text { and showed better } \\
\text { implant precision in } \\
\text { CBCT than the other } \\
\text { groups. Students pre- } \\
\text { ferred the combined } \\
\text { of jawbone and VR } \\
\text { reality simulation }\end{array}$ \\
\hline 5 & $\begin{array}{l}\text { Zorzal et } \\
\text { al } 2021 \\
\text { Brazil }^{71}\end{array}$ & $\begin{array}{l}\text { IMMPLANT } \\
\text { VR simu- } \\
\text { lator uses } \\
\text { smartphone } \\
\text { and laptops }\end{array}$ & $\begin{array}{l}\text { (16) dental } \\
\text { postgraduates }\end{array}$ & CST & $\begin{array}{l}\text { Place a virtual } \\
\text { implant at a specific } \\
\text { bone-loss area } \\
\text { location within a } \\
\text { subject-specific 3D } \\
\text { model of a lower jaw }\end{array}$ & $\begin{array}{l}\text { Participants feedback } \\
\text { regarding benefits and } \\
\text { limitations }\end{array}$ & $\begin{array}{l}\text { VR system is easy to } \\
\text { use and promotes } \\
\text { greater spatial } \\
\text { awareness of the } \\
\text { 3D dental model } \\
\text { and easy to learn } \\
\text { but they reported } \\
\text { difficulty selecting } \\
\text { the predetermined } \\
\text { implant position and } \\
\text { inclination }\end{array}$ \\
\hline
\end{tabular}

Abbreviations: CST, cross sectional trial; DS, dental students; RCT, randomized controlled trial; VR, virtual reality.

theoretical knowledge acquisition. VP reduced anxiety associated with real patient's management while executing a treatment plan, exposed students to an interactive learning experience, enriched self-assessed competence, and augmented confidence to deal with actual patients. As simulators offer flexibility in terms of time, this allowed the students to repeat the procedure until they demonstrate acceptable skill levels without violating real patients and eliminating the need for prolonged direct contact. ${ }^{47-49,53,77}$ Still, VP for dental training requires further development to simulate the patient's oral environment of gingival tissues, saliva, tongue movements, and reflexes as gagging, cough, and head movements. Accordingly, it would aid in teaching emergency management in the dental setting. ${ }^{75}$

Fourth, VR applications with real-time dental training and evaluation systems were very beneficial in acquiring motor skills in preclinical settings. It allowed instantaneous feedback of the students' performance, enhanced students' self-assessment, and correction and eliminated the subjectivity of evaluation..$^{59,64,65}$ Nevertheless, dental students indicated that the simulating devices' instructions and feedback should be adjunctive to but not a replacement to the faculty feedback. 
Table 6 Characteristics of the selected studies in oral and maxillofacial radiology

\begin{tabular}{|c|l|l|l|l|l|l|l|}
\hline $\begin{array}{l}\text { S. } \\
\text { no }\end{array}$ & $\begin{array}{l}\text { Author, Year, } \\
\text { Country }\end{array}$ & VR system & Participants & $\begin{array}{l}\text { Study } \\
\text { design }\end{array}$ & $\begin{array}{l}\text { Assessment } \\
\text { tool }\end{array}$ & Tested outcome & Results \\
\hline 1 & $\begin{array}{l}\text { Nilsson } \\
\text { et al 2011, } \\
\text { Sweden }\end{array}$ & $\begin{array}{l}\text { VR simula- } \\
\text { tor-supported } \\
\text { training }\end{array}$ & $\begin{array}{l}\text { (45) 4th and 5th } \\
\text { year DS }\end{array}$ & RCT & $\begin{array}{l}\text { Comparison of } \\
\text { base line and } \\
\text { after interven- } \\
\text { tion theoretical } \\
\text { examination }\end{array}$ & $\begin{array}{l}\text { Skill at inter- } \\
\text { preting spatial } \\
\text { information in } \\
\text { radiographs }\end{array}$ & $\begin{array}{l}\text { Radiographic inter- } \\
\text { pretation skills } 8 \text { mo } \\
\text { after simulator-sup- } \\
\text { ported training was } \\
\text { significantly better than } \\
\text { before training }\end{array}$ \\
\hline 2 & $\begin{array}{l}\text { Soltanimehr } \\
\text { et al 2019, } \\
\text { Iran }\end{array}$ & $\begin{array}{l}\text { Virtual learning } \\
\text { management } \\
\text { system (LMS) }\end{array}$ & (39) 4th year DS & RCT & $\begin{array}{l}\text { Theoretical test } \\
\text { with MCQs and } \\
\text { objective struc- } \\
\text { tured clinical } \\
\text { examination } \\
\text { (OSCE) at base } \\
\text { line and after } \\
\text { 2 mo }\end{array}$ & $\begin{array}{l}\text { Radiographic } \\
\text { interpretation of } \\
\text { bony lesions }\end{array}$ & $\begin{array}{l}\text { Scores of the virtual } \\
\text { group were signif- } \\
\text { icantly higher in } \\
\text { theoretical exam but } \\
\text { insignificant in OSCE. } \\
\text { After } 2 \text { mo difference } \\
\text { was not statistically } \\
\text { significant }\end{array}$ \\
\hline
\end{tabular}

Abbreviations: DS, dental students; MCQs, multiple choice questions; OSCE, objective structured clinical examination; RCT, randomized controlled trial; VR, virtual reality.

Table 7 Characteristics of the selected studies in periodontology

\begin{tabular}{|l|l|l|l|l|l|l|l|}
\hline $\begin{array}{l}\text { S. } \\
\text { no }\end{array}$ & $\begin{array}{l}\text { Author, Year, } \\
\text { Country }\end{array}$ & VR system & Participants & $\begin{array}{l}\text { Study } \\
\text { design }\end{array}$ & Assessment tool & $\begin{array}{l}\text { Tested } \\
\text { outcome }\end{array}$ & Results \\
\hline 1 & $\begin{array}{l}\text { Wang et al } \\
\text { 2012, China }\end{array}$ & $\begin{array}{l}\text { iDental hap- } \\
\text { tic-based } \\
\text { simulator }\end{array}$ & $\begin{array}{l}\text { (19) Dental grad- } \\
\text { uates, (10) faculty } \\
\text { members }\end{array}$ & $\begin{array}{l}\text { CST } \\
\text { Virtual tasks of } \\
\text { periodontal pocket } \\
\text { probing, and } \\
\text { calculus detec- } \\
\text { tion and removal, } \\
\text { followed by user } \\
\text { questionnaire }\end{array}$ & $\begin{array}{l}\text { Realism of the } \\
\text { simulator rela- } \\
\text { tive to clinical } \\
\text { situations }\end{array}$ & $\begin{array}{l}\text { Participants reported } \\
\text { highly realistic shape } \\
\text { of teeth, gingivae, } \\
\text { periodontal tools, and } \\
\text { oral environment, but } \\
\text { poor realistic shape of } \\
\text { the calculus and FFB }\end{array}$ \\
\hline 2 & $\begin{array}{l}\text { Yamaguchi } \\
\text { et al 2013, } \\
\text { Japan }\end{array}$ & $\begin{array}{l}\text { Haptic- } \\
\text { based } \\
\text { simulator }\end{array}$ & (26) 4th year DS & CST & $\begin{array}{l}\text { Carries removal } \\
\text { and periodontal } \\
\text { pocket probing } \\
\text { in three training } \\
\text { sessions }\end{array}$ & $\begin{array}{l}\text { Carries } \\
\text { removal. } \\
\text { Periodontal } \\
\text { pocket probing } \\
\text { skills }\end{array}$ & $\begin{array}{l}\text { The mean scores from } \\
\text { the training sessions } \\
\text { were significantly } \\
\text { higher than the mean } \\
\text { pre-training score for } \\
\text { both carries removal } \\
\text { and periodontal pocket } \\
\text { probing skills }\end{array}$ \\
\hline
\end{tabular}

Abbreviations: CST, cross sectional trial; DS, dental students; FFB, force feedback; VR, virtual reality.

Faculty should be attentive to their responsibility in teaching young dentists, treating patients with individual needs, requiring empathy and informed consent for any treatment decision. The faculty's role-model function is essential when supervising students during patient treatment in clinical practices, complex problem solving, in-depth conceptual coverage, and peer interaction. Continuous training with faculty supervision and feedback is still an anticipated key to good dental education.

Fifth, most of the studies applied VR through academic laboratories, a fact that should be reconsidered, and alternative mobile platforms should be developed. To benefit from the technology, the student must be physically present on the academic campus. This situation limits to a great extent the range of getting most of the benefit of the virtual technology due to the condensed academic timetables and the increased training times required. Meanwhile, curriculum designers should notice that virtual applications on personal computers and mobiles might leave the whole education process in the student's hands, for whom some can organize their time accordingly, while others cannot. Thus, supervisors and teachers must monitor the learning process since a lack of motivation in some students would downgrade the technology's benefit. ${ }^{13}$ In this context, tutors should operate continuous assessment in the form of pop-up quizzes, group discussions, and scheduled assignments or presentations, which would eventually lead to a blended form of learning, highlighting the teacher's role. ${ }^{48}$

Based on the results of this review, it is recommended that low-cost VR hard and software be made readily available to create safe and cost-effective interactive educational training, allowing learners and trainees instantaneous engagement through their personal computers or mobiles. It is advised to clarify learning contents and the extent to which conventional workflows should be taught, aside from the virtual content. One form of a teaching strategy that should be utilized on a wider scale is educational video games. This form of educational material elevated students' enthusiasm for learning and made learning an enjoyable process. $^{42,84}$ Young generations are more prominent in 
Table 8 Characteristics of the selected studies in pediatric dentistry

\begin{tabular}{|c|c|c|c|c|c|c|c|}
\hline $\begin{array}{l}\text { S. } \\
\text { no }\end{array}$ & $\begin{array}{l}\text { Author, Year, } \\
\text { Country }\end{array}$ & VR system & Participants & $\begin{array}{l}\text { Study } \\
\text { design }\end{array}$ & Assessment tool & Tested outcome & Results \\
\hline 1 & $\begin{array}{l}\text { Papadopoulos } \\
\text { et al } 2013 \text { in } \\
\text { Greece }^{77}\end{array}$ & $\begin{array}{l}\text { VR sim- } \\
\text { ulation pedi- } \\
\text { atric VP }\end{array}$ & $\begin{array}{l}\text { (103) 4th year } \\
\text { DS }\end{array}$ & RCT & $\begin{array}{l}\text { - MCQs knowledge } \\
\text { questionnaire } \\
\text { - VP feedback }\end{array}$ & $\begin{array}{l}\text { Students' knowl- } \\
\text { edge of behavior } \\
\text { and communi- } \\
\text { cation pediatric } \\
\text { dentistry }\end{array}$ & $\begin{array}{l}\text { VP group had signif- } \\
\text { icantly higher scores } \\
\text { and the majority } \\
\text { evaluated the aspects } \\
\text { of the simulation very } \\
\text { positively }\end{array}$ \\
\hline 2 & $\begin{array}{l}\text { Mladenovic et al } \\
2020 \text { in Serbia }\end{array}$ & $\begin{array}{l}\text { AR } \\
\text { simulator }\end{array}$ & $\begin{array}{l}\text { (21) Fourth } \\
\text { and fifth year } \\
\text { DS }\end{array}$ & RCT & $\begin{array}{l}\text { The time taken } \\
\text { to administer the } \\
\text { anesthesia. Level } \\
\text { of salivary cortisol } \\
\text { before and after } \\
\text { Level of salivary cor- } \\
\text { tisol before and after } \\
\text { the administration of } \\
\text { anesthesia }\end{array}$ & $\begin{array}{l}\text { Perception of } \\
\text { learning and } \\
\text { acute stress level }\end{array}$ & $\begin{array}{l}\text { AR group reported } \\
\text { significantly shorter } \\
\text { time. The level of } \\
\text { cortisol signifi- } \\
\text { cantly increased no } \\
\text { statistical difference } \\
\text { between the groups }\end{array}$ \\
\hline 3 & $\begin{array}{l}\text { Zafar et al 2020, } \\
\text { Australia }^{79}\end{array}$ & $\begin{array}{l}\text { Simodont } \\
\text { Haptic } \\
\text { simulator }\end{array}$ & $\begin{array}{l}\text { (100) } \\
\text { Doctorate } \\
\text { degree } \\
\text { students }\end{array}$ & $\mathrm{CCO}$ & $\begin{array}{l}\text { Traditional and } \\
\text { simulator training } \\
\text { on pulpotomies and } \\
\text { stainless-steel crowns } \\
\text { (SSCs), followed by a } \\
\text { questionnaire }\end{array}$ & $\begin{array}{l}\text { Experience of } \\
\text { pulpotomy and } \\
\text { SSCs procedures } \\
\text { on the Simodont, } \\
\text { vs. conventional } \\
\text { training }\end{array}$ & $\begin{array}{l}\text { Over } 50 \% \text { agreed that } \\
\text { Simodont-assisted } \\
\text { learning, and facili- } \\
\text { tated understanding } \\
\text { of pediatric dentistry } \\
\text { tasks, although they } \\
\text { felt more comfortable } \\
\text { with the conventional } \\
\text { training setup }\end{array}$ \\
\hline 4 & $\begin{array}{l}\text { Zafar et al 2021, } \\
\text { Australia }^{80}\end{array}$ & $\begin{array}{l}\text { Oculus } \\
\text { Quest (VR } \\
\text { headset plus } \\
\text { digital } \\
\text { 3D holo- } \\
\text { grams and } \\
\text { 360-degree } \\
\text { spatial } \\
\text { sound) }\end{array}$ & $\begin{array}{l}\text { (71) Second } \\
\text { year DS }\end{array}$ & CST & $\begin{array}{l}\text { Self-administered } \\
\text { questionnaire before } \\
\text { and after the use } \\
\text { of dental LAVR } \\
\text { simulator }\end{array}$ & $\begin{array}{l}\text { Dental student's } \\
\text { perception of } \\
\text { dental LAVR } \\
\text { simulation on a } \\
\text { pediatric patient }\end{array}$ & $\begin{array}{l}\text { Most of the par- } \\
\text { ticipants reported } \\
\text { improved LA skills, } \\
\text { more engaged in } \\
\text { the learning activity, } \\
\text { improved under- } \\
\text { standing of anatom- } \\
\text { ical landmarks, and } \\
\text { added value com- } \\
\text { pared with traditional } \\
\text { LA teaching methods }\end{array}$ \\
\hline
\end{tabular}

Abbreviations: AR, augmented reality; CCO, comparative crossover; CST, cross sectional trial; DS, dental students; LAVR, local anesthesia virtual reality; MCQs, multiple choice questions; RCT, randomized controlled trial; VP, virtual patient; VR, virtual reality.

Table 9 Characteristics of the selected studies in miscellaneous dental skills

\begin{tabular}{|l|l|l|l|l|l|l|l|}
\hline $\begin{array}{l}\text { S. } \\
\text { no }\end{array}$ & $\begin{array}{l}\text { Author, Year, } \\
\text { Country }\end{array}$ & VR system & Participants & $\begin{array}{l}\text { Study } \\
\text { design }\end{array}$ & $\begin{array}{l}\text { Assessment } \\
\text { tool }\end{array}$ & Tested outcome & Results \\
\hline 1 & $\begin{array}{l}\text { Allaire 2015, } \\
\text { United } \\
\text { States }\end{array}$ & $\begin{array}{l}\text { VP in critical think- } \\
\text { ing assessment }\end{array}$ & $\begin{array}{l}\text { (31) Senior } \\
\text { hygiene DS }\end{array}$ & CST & $\begin{array}{l}\text { Pre- and } \\
\text { post-theoretical } \\
\text { MCQs test and } \\
\text { questionnaire }\end{array}$ & $\begin{array}{l}\text { Skills of critical thinking, } \\
\text { problem solving, and } \\
\text { confidence }\end{array}$ & $\begin{array}{l}\text { Insignificant increase } \\
\text { in students' scores } \\
\text { although they } \\
\text { reported VP an } \\
\text { effective teaching } \\
\text { method in enhancing } \\
\text { self-confidence with } \\
\text { real patients }\end{array}$ \\
\hline 2 & $\begin{array}{l}\text { Marei et al } \\
\begin{array}{l}\text { Arabia } \\
\text { A3 }\end{array}\end{array}$ & $\begin{array}{l}\text { Five VP for teaching } \\
\text { professionalism }\end{array}$ & $\begin{array}{l}\text { (65) First year } \\
\text { DS }\end{array}$ & CST & $\begin{array}{l}\text { Structured } \\
\text { questionnaire } \\
\text { before and after } \\
\text { training }\end{array}$ & $\begin{array}{l}\text { Students' perception } \\
\text { toward the use of VPs } \\
\text { in developing ethical } \\
\text { reasoning skills }\end{array}$ & $\begin{array}{l}\text { High-fidelity VPs were } \\
\text { significantly better } \\
\text { for developing ethical } \\
\text { reasoning skills }\end{array}$ \\
\hline 3 & $\begin{array}{l}\text { El Tantawi } \\
\text { et al 2018, } \\
\text { Saudi Arabia }\end{array}$ & $\begin{array}{l}\text { DentLit video } \\
\text { game to develop } \\
\text { academic writing } \\
\text { skills }\end{array}$ & $\begin{array}{l}\text { (92) First year } \\
\text { DS }\end{array}$ & $\begin{array}{l}\text { Quasi } \\
\text { experiment }\end{array}$ & $\begin{array}{l}\text { Pre- and post-in- } \\
\text { tervention } \\
\text { assessment of } \\
\text { students' aca- } \\
\text { demic writing } \\
\text { skills }\end{array}$ & $\begin{array}{l}\text { 1. Satisfaction } \\
\text { of students with } \\
\text { gamification } \\
\text { 2. Perceived and } \\
\text { actual improvement } \\
\text { of academic writing }\end{array}$ & $\begin{array}{l}\text { Significant improve- } \\
\text { ment in actual } \\
\text { writing. Overall sat- } \\
\text { isfaction with game } \\
\text { aspects was modest } \\
\text { and significantly asso- } \\
\text { ciated with improve- } \\
\text { ment of writing }\end{array}$ \\
\hline
\end{tabular}


Table 9 (continued)

\begin{tabular}{|c|c|c|c|c|c|c|c|}
\hline $\begin{array}{l}\text { S. } \\
\text { no }\end{array}$ & $\begin{array}{l}\text { Author, } \\
\text { Year, } \\
\text { Country }\end{array}$ & VR system & Participants & $\begin{array}{l}\text { Study } \\
\text { design }\end{array}$ & $\begin{array}{l}\text { Assessment } \\
\text { tool }\end{array}$ & Tested outcome & Results \\
\hline 4 & $\begin{array}{l}\text { Takagi et al } \\
\text { 2019, Japan }\end{array}$ & $\begin{array}{l}\text { IVR for teaching } \\
\text { home dental } \\
\text { practice }\end{array}$ & (101) DS & CST & $\begin{array}{l}\text { Survey before } \\
\text { and after } \\
\text { watching the } \\
\text { VR teaching } \\
\text { material }\end{array}$ & $\begin{array}{l}\text { Changes in self-confi- } \\
\text { dence regarding knowl- } \\
\text { edge of home dental } \\
\text { practice and treatment } \\
\text { assistance }\end{array}$ & $\begin{array}{l}\text { A significant increase } \\
\text { in student's knowl- } \\
\text { edge confidence and } \\
\text { assistance confidence } \\
\text { scores }\end{array}$ \\
\hline 5 & $\begin{array}{l}\text { Zafar and } \\
\text { Zachar 2020, } \\
\text { Australia }^{86}\end{array}$ & $\begin{array}{l}\text { HoloHuman AR } \\
\text { to teach head and } \\
\text { neck anatomy }\end{array}$ & $\begin{array}{l}(88) \text { Second } \\
\text { year DS }\end{array}$ & CST & $\begin{array}{l}\text { Self- } \\
\text { administered } \\
\text { questionnaire } \\
\text { before and after } \\
\text { the use of AR }\end{array}$ & Perceptions of the AR & $\begin{array}{l}\text { AR improved ana- } \\
\text { tomical structures } \\
\text { learning and under- } \\
\text { standing, and they felt } \\
\text { more confident, but } \\
\text { it should not replace } \\
\text { traditional cadaver } \\
\text { training }\end{array}$ \\
\hline 6 & $\begin{array}{l}\text { Liebermann } \\
\text { and Erdelt. } \\
2020, \\
\text { Germany }^{87}\end{array}$ & $\begin{array}{l}\text { VR in learning den- } \\
\text { tal morphologies }\end{array}$ & $\begin{array}{l}\text { (48) Second } \\
\text { year DS }\end{array}$ & CST & Questionnaire & Students' acceptance & $\begin{array}{l}\text { Most of the students } \\
\text { understood dental } \\
\text { morphologies much } \\
\text { better compared with } \\
\text { traditional textbook }\end{array}$ \\
\hline 7 & $\begin{array}{l}\text { Tsai et al } \\
\text { 2020, United } \\
\text { States }^{88}\end{array}$ & $\begin{array}{l}\text { Mobile multimedia } \\
\text { platform to teach } \\
\text { dental diagnosis }\end{array}$ & $\begin{array}{l}\text { (89) } \\
\text { Predoctoral DS }\end{array}$ & CST & \begin{tabular}{|l|} 
Baseline and 4-d \\
later theoret- \\
ical test and \\
questionnaire
\end{tabular} & $\begin{array}{l}\text { Basic dental diagnostic } \\
\text { skills }\end{array}$ & $\begin{array}{l}\text { Test scores increased } \\
\text { significantly. Most stu- } \\
\text { dents agreed on the } \\
\text { ease of access and use } \\
\text { of the platform and } \\
\text { preferred Instagram } \\
\text { stories over traditional } \\
\text { lectures }\end{array}$ \\
\hline 8 & $\begin{array}{l}\text { Amini et al } \\
\text { 2021, United } \\
\text { States }^{89}\end{array}$ & $\begin{array}{l}\text { IVR to teach social } \\
\text { aspects of dental } \\
\text { care delivery }\end{array}$ & $\begin{array}{l}\text { (29) Dental } \\
\text { residents }\end{array}$ & CST & $\begin{array}{l}\text { Pre, immediately } \\
\text { after and after } \\
\text { 1-mo survey }\end{array}$ & $\begin{array}{l}\text { Knowledge, skills, and } \\
\text { attitude toward social } \\
\text { determinants of health }\end{array}$ & $\begin{array}{l}\text { Significant increased } \\
\text { mean scores for } \\
\text { cognitive, affective, } \\
\text { and skill-based } \\
\text { learning immedi- } \\
\text { ately post-training } \\
\text { and no significant } \\
\text { changes after 1-mo. } \\
\text { Participants reported } \\
\text { high satisfaction } \\
\text { with the content and } \\
\text { methods used in this } \\
\text { training }\end{array}$ \\
\hline
\end{tabular}

Abbreviations: AR, augmented reality; CST, cross sectional trial; DS, dental students; IVR, immersive virtual reality; VP, virtual patients; VR, virtual reality.

adapting to new technologies and increasingly familiarized with video games, encouraging further development and improvements in this field to introduce education with more fun.

\section{Limitations}

Our study has several limitations. The retrospective nature of our review, incorporating data from published studies and not on individual patients, limits the availability of information on some issues as long-term follow-up of the students and the influence of VR on clinical practices. The search process revealed heterogenous studies addressing the systematic review's aim, and while meta-analysis was not feasible, we conducted a descriptive approach for identifying the effective outcome of virtual applications. Custom-made software was only used by authors who first described them, which is a significant flaw and could represent a conflict of interest in validating a new proposed system. Also, there was a lack of randomized clinical trials with a proper sample size calculation and other efforts to avoid major bias.

\section{Conclusion}

Advanced simulation technology improved the quality of dental education outcomes. It offered applications in different dental disciplines and various clinical procedures. HT enhanced manual skills and perceived self-confidence within few clinical sessions. The most remarkable improvement was the cavity walls convergence, pulpal floor, extension of class I, cavity outline, fewer pulpal exposure, and faster preparation. Students performed better in 3D than 2D vision, with FFB than without, and with a combined instructor and device feedback than with instructor or device feedback alone. Quality of crown preparation and implant placement improved over time after using VR with or without 
instructor's feedback. AR reinforced orthognathic surgical training, virtual apicectomies, and local anesthesia administration. Application of VR improved acquisition of theoretical knowledge to a lesser extent. The role of the teacher and verbal instructions cannot be ruled out.

Conflict of Interest

None declared.

\section{References}

1 Perry S, Bridges SM, Burrow MF. A review of the use of simulation in dental education. Simul Healthc 2015;10(1):31-37

2 Pottle J. Virtual reality and the transformation of medical education. Future Healthc J 2019;6(3):181-185

3 Serrano CM, Wesselink PR, Vervoorn JM. First experiences with patient-centered training in virtual reality. J Dent Educ 2020;84(5):607-614

4 Dixon J, Towers A, Martin N, Field J. Re-defining the virtual reality dental simulator: demonstrating concurrent validity of clinically relevant assessment and feedback. Eur J Dent Educ 2021;25(1):108-116

5 Khurshid Z, Asiri FYI, Al Wadaani H. Human saliva: non-invasive fluid for detecting novel coronavirus (2019-nCoV). Int J Environ Res Public Health 2020;17(7):17-20

6 Towers A, Field J, Stokes C, Maddock S, Martin N. A scoping review of the use and application of virtual reality in pre-clinical dental education. Br Dent J 2019;226(5):358-366

7 Dutã M, Amariei CI, Bogdan CM, Popovici DM, Ionescu N, Nuca $\mathrm{CI}$. An overview of virtual and augmented reality in dental education. Oral Heal Dent Manag 2011;10(1):42-49

8 Wu HK, Lee SW, Chang H, Liang JC. Current status, opportunities and challenges of augmented reality in education. Comput Educ 2013;62:41-49

9 Farronato M, Maspero C, Lanteri V, et al. Current state of the art in the use of augmented reality in dentistry: a systematic review of the literature. BMC Oral Health 2019;19(1):135

10 Yoshida Y, Yamaguchi S, Kawamoto Y, Noborio H, Murakami S, Sohmura T. Development of a multi-layered virtual tooth model for the haptic dental training system. Dent Mater J 2011;30(1):1-6

11 de Boer IR, Wesselink PR, Vervoorn JM. The creation of virtual teeth with and without tooth pathology for a virtual learning environment in dental education. Eur J Dent Educ 2013;17(4):191-197

12 Al-Saud LM, Mushtaq F, Allsop MJ, et al. Feedback and motor skill acquisition using a haptic dental simulator. Eur J Dent Educ 2017;21(4):240-247

13 Llena C, Folguera S, Forner L, Rodríguez-Lozano FJ. Implementation of augmented reality in operative dentistry learning. Eur J Dent Educ 2018;22(1):e122-e130

14 Suebnukarn S, Rhienmora P, Haddawy P. The use of cone-beam computed tomography and virtual reality simulation for pre-surgical practice in endodontic microsurgery. Int Endod J 2012;45(7):627-632

15 Pohlenz P, Gröbe A, Petersik A, et al. Virtual dental surgery as a new educational tool in dental school. J Craniomaxillofac Surg 2010;38(8):560-564

16 Huang T-K, Yang C-H, Hsieh Y-H, Wang J-C, Hung C-C. Augmented reality (AR) and virtual reality (VR) applied in dentistry. Kaohsiung J Med Sci 2018;34(4):243-248

17 Kwon H-B, Park Y-S, Han J-S. Augmented reality in dentistry: a current perspective. Acta Odontol Scand 2018;76(7):497-503

18 Ayoub A, Pulijala Y. The application of virtual reality and augmented reality in Oral \& Maxillofacial Surgery. BMC Oral Health 2019;19(1):238
19 Iwanaga J, Kamura Y, Nishimura Y, et al. A new option for education during surgical procedures and related clinical anatomy in a virtual reality workspace. Clin Anat 2021;34(3):496-503

20 Liberati A, Altman DG, Tetzlaff J, et al. The PRISMA statement for reporting systematic reviews and meta-analyses of studies that evaluate healthcare interventions: explanation and elaboration. BMJ 2009;339:b2700

21 Higgins JPT, Thomas J, Chandler J, et al, eds. Cochrane Handbook for Systematic Reviews of Interventions version 6.1 (updated September 2020). Cochrane; 2020. Available at: www.training.cochrane.org/handbook. Accessed October 12, 2020

22 Urbankova A, Engebretson SP. The use of haptics to predict preclinic operative dentistry performance and perceptual ability. J Dent Educ 2011;75(12):1548-1557

23 de Boer IR, Lagerweij MD, de Vries MW, Wesselink PR, Vervoorn JM. The effect of force feedback in a virtual learning environment on the performance and satisfaction of dental students. Simul Healthc 2017;12(2):83-90

24 Ria S, Cox MJ, Quinn BF, San Diego JP, Bakir A, Woolford MJ. A scoring system for assessing learning progression of dental students' clinical skills using haptic virtual workstations. J Dent Educ 2018;82(3):277-285

25 Dwisaptarini AP, Suebnukarn S, Rhienmora P, Haddawy P, Koontongkaew S. Effectiveness of the multilayered caries model and visuo-tactile virtual reality simulator for minimally invasive caries removal: a randomized controlled trial. Oper Dent 2018;43(3):E110-E118

26 Mirghani I, Mushtaq F, Allsop MJ, et al. Capturing differences in dental training using a virtual reality simulator. Eur J Dent Educ 2018;22(1):67-71

27 de Boer IR, Lagerweij MD, Wesselink PR, Vervoorn JM. The effect of variations in force feedback in a virtual reality environment on the performance and satisfaction of dental students. Simul Healthc 2019;14(3):169-174

28 Vincent M, Joseph D, Amory C, et al. Contribution of haptic simulation to analogic training environment in restorative dentistry. J Dent Educ 2020;84(3):367-376

29 Murbay S, Neelakantan P, Chang JWW, Yeung S. 'Evaluation of the introduction of a dental virtual simulator on the performance of undergraduate dental students in the pre-clinical operative dentistry course' Eur J Dent Educ 2020;24(1):5-16

30 Osnes C, Duke A, Wu J, Franklin P, Mushtaq F, Keeling A. Investigating the construct validity of a haptic virtual caries simulation for dental education. BMJ Simul Technol Enhanc Learn 2021;7(2):81-85

31 Urbankova A, Eber M, Engebretson SP. A complex haptic exercise to predict preclinical operative dentistry performance: a retrospective study. J Dent Educ 2013;77(11):1443-1450

32 Bakr MM, Massey W, Alexander H. Students' evaluation of a 3DVR haptic device (Simodont ${ }^{\circledR}$ ). Does early exposure to haptic feedback during preclinical dental education enhance the development of psychomotor skills? Int J Dent Clin 2014;6(2):1-7

33 Koo S, Kim A, Donoff RB, Karimbux NY. An initial assessment of haptics in preclinical operative dentistry training. J Investig Clin Dent 2015;6(1):69-76

34 Cox M, Ria S, Quinn B, San Diego J, Woolford M. An investigation into the clinical skills performance of year 1 dental undergraduate students' using haptel-a haptic virtual dental simulator which provides individual student feedback. Paper presented at: Proceedings of the 14th Anglo-Italian Conference; 2016 April; Brescia, Italy

35 San Diego J, Cox M, Quinn B, Ria S, San Diego J, Woolford M. Performance of students' clinical skills using a haptic dental simulator. Paper presented at: Proceedings of International Association for Dental Research; 2016 June; Seoul, Korea 
36 de Boer IR, Wesselink PR, Vervoorn JM. Student performance and appreciation using 3D vs. 2D vision in a virtual learning environment. Eur J Dent Educ 2016;20(3):142-147

37 Shahriari-Rad A, Cox M, Woolford M. Clinical skills acquisition: rethinking assessment using a virtual haptic simulator. Technol Knowl Learn 2017;22(2):185-197

38 Cox M, Quinn B, Shahriari-Rad A, San Diego J, Woolford M. Innovative techniques to assess the performance of cavity preparation skills. Paper presented at: Proceedings of International Association for Dental Research; 2017 March; San Francisco, California

39 Urbankova A. Impact of computerized dental simulation training on preclinical operative dentistry examination scores. J Dent Educ 2010;74(4):402-409

40 Tubelo RA, Branco VL, Dahmer A, Samuel SM, Collares FM. The influence of a learning object with virtual simulation for dentistry: a randomized controlled trial. Int J Med Inform 2016;85(1):68-75

41 Gottlieb R, Baechle MA, Janus C, Lanning SK. Predicting performance in technical preclinical dental courses using advanced simulation. J Dent Educ 2017;81(1):101-109

42 Amer RS, Denehy GE, Cobb DS, Dawson DV, CunninghamFord MA, Bergeron C. Development and evaluation of an interactive dental video game to teach dentin bonding. J Dent Educ 2011;75(6):823-831

43 Suebnukarn S, Haddawy P, Rhienmora P, Jittimanee P, Viratket P. Augmented kinematic feedback from haptic virtual reality for dental skill acquisition. J Dent Educ 2010;74(12):1357-1366

44 Suebnukarn S, Hataidechadusadee R, Suwannasri N, Suprasert N, Rhienmora P, Haddawy P. Access cavity preparation training using haptic virtual reality and microcomputed tomography tooth models. Int Endod J 2011;44(11):983-989

45 Wang D, Zhao S, Li T, Zhang Y, Wang X. Preliminary evaluation of a virtual reality dental simulation system on drilling operation. Biomed Mater Eng 2015;26(Suppl 1):S747-S756

46 Reymus M, Liebermann A, Diegritz C. Virtual reality: an effective tool for teaching root canal anatomy to undergraduate dental students-a preliminary study. Int Endod J 2020;53(11):1581-1587

47 Clark GT, Suri A, Enciso R. Autonomous virtual patients in dentistry: system accuracy and expert versus novice comparison. J Dent Educ 2012;76(10):1365-1370

48 Seifert LB, Socolan O, Sader R, Rüsseler M, Sterz J. Virtual patients versus small-group teaching in the training of oral and maxillofacial surgery: a randomized controlled trial. BMC Med Educ 2019;19(1):454

49 Mardani M, Cheraghian S, Naeeni SK, Zarifsanaiey N. Effectiveness of virtual patients in teaching clinical decision-making skills to dental students. J Dent Educ 2020;84(5):615-623

50 McAlpin E, Bergner Y, Levine M. Summative assessments of web-based patient simulations of pre-clinical local anaesthesia and non-surgical extraction. Eur J Dent Educ 2020;00:1-11

51 Mladenovic R, Pereira LAP, Mladenovic K, Videnovic N, Bukumiric Z, Mladenovic J. Effectiveness of augmented reality mobile simulator in teaching local anesthesia of inferior alveolar nerve block. J Dent Educ 2019;83(4):423-428

52 Mladenovic R, Bukumiric Z, Mladenovic K. Practice of local anesthesia applications in 3D environment during the COVID-19 pandemic. J Dent Educ 2020. Doi: 10.1002/jdd.12410

53 Sakowitz SM, Inglehart MR, Ramaswamy V, et al. A comparison of two-dimensional prediction tracing and a virtual reality patient methods for diagnosis and treatment planning of orthognathic cases in dental students: a randomized preliminary study. Virtual Real (Walth Cross) 2020;24(3):399-409
54 Pulijala Y, Ma M, Pears M, Peebles D, Ayoub A. Effectiveness of immersive virtual reality in surgical training-a randomized control trial. J Oral Maxillofac Surg 2018;76(5):1065-1072

55 Collaço E, Kira E, Sallaberry LH, et al. Immersion and haptic feedback impacts on dental anesthesia technical skills virtual reality training. J Dent Educ 2020;00:1-10

56 Lin WS, Chou JC, Charette JR, Metz MJ, Harris BT, Choi N. Creating virtual 3-dimensional models for teaching pre-clinical tooth preparation: Students' usages and perceptions. Eur J Dent Educ 2018;22(3):e573-e581

57 Mai HY, Mai HN, Lee DH. Computer-based 3D simulation method in dental occlusion education: student response and learning effect. Appl Sci (Basel) 2020;10(17):6073

58 Kikuchi H, Ikeda M, Araki K. Evaluation of a virtual reality simulation system for porcelain fused to metal crown preparation at Tokyo Medical and Dental University. J Dent Educ 2013;77(6):782-792

59 Hamil LM, Mennito AS, Renné WG, Vuthiganon J. Dental students' opinions of preparation assessment with E4D compare software versus traditional methods. J Dent Educ 2014;78(10):1424-1431

60 Eve EJ, Koo S, Alshihri AA, et al. Performance of dental students versus prosthodontics residents on a $3 \mathrm{D}$ immersive haptic simulator. J Dent Educ 2014;78(4):630-637

61 Callan RS, Palladino CL, Furness AR, Bundy EL, Ange BL. Effectiveness and feasibility of utilizing E4D technology as a teaching tool in a preclinical dental education environment. J Dent Educ 2014;78(10):1416-1423

62 Liu L, Li J, Yuan S, et al. Evaluating the effectiveness of a preclinical practice of tooth preparation using digital training system: a randomised controlled trial. Eur J Dent Educ 2018;22(4):e679-e686

63 Kozarovska A, Larsson C. Implementation of a digital preparation validation tool in dental skills laboratory training. Eur J Dent Educ 2018;22(2):115-121

64 Nagy ZA, Simon B, Tóth Z, Vág J. Evaluating the efficiency of the Dental Teacher system as a digital preclinical teaching tool. Eur J Dent Educ 2018;22(3):e619-e623

65 Liu L, Zhou R, Yuan S, et al. Simulation training for ceramic crown preparation in the dental setting using a virtual educational system. Eur J Dent Educ 2020;24(2):199-206

66 Tang L, Cao Y, Liu Z, et al. Improving the quality of preclinical simulation training for dental students using a new digital real-time evaluation system. Eur J Dent Educ 2021;25(1):100-107

67 Al-Saud LM, Mushtaq F, Mann RP, et al. Early assessment with a virtual reality haptic simulator predicts performance in clinical practice. BMJ Simul Technol Enhanc Learn 2020;6(5):274-278

68 Joseph D, Jehl J-P, Maureira P, et al. Relative contribution of haptic technology to assessment and training in implantology. BioMed Res Int 2014;2014:413951

69 Golob Deeb J, Bencharit S, Carrico CK, et al. Exploring training dental implant placement using computer-guided implant navigation system for predoctoral students: a pilot study. Eur J Dent Educ 2019;23(4):415-423

70 Zhang B, Li S, Gao S, et al. Virtual versus jaw simulation in oral implant education: a randomized controlled trial. BMC Med Educ 2020;20(1):272

71 Zorzal ER, Paulo SF, Rodrigues P, Mendes JJ, Lopes DS. An immersive educational tool for dental implant placement: a study on user acceptance. Int J Med Inform 2021;146:104342

72 Qi S, Yan Y, Li R, Hu J. The impact of active versus passive use of 3D technology: a study of dental students at Wuhan University, China. J Dent Educ 2013;77(11):1536-1542

73 Nilsson TA, Hedman LR, Ahlqvist JB. Dental student skill retention eight months after simulator-supported training in oral radiology. J Dent Educ 2011;75(5):679-684 
74 Soltanimehr E, Bahrampour E, Imani MM, Rahimi F, Almasi B, Moattari M. Effect of virtual versus traditional education on theoretical knowledge and reporting skills of dental students in radiographic interpretation of bony lesions of the jaw. BMC Med Educ 2019;19(1):233

75 Wang D, Zhang Y, Hou J, et al. IDental: a haptic-based dental simulator and its preliminary user evaluation. IEEE Trans Haptics 2012;5(4):332-343

76 Yamaguchi S, Yoshida Y, Noborio H, Murakami S, Imazato S. The usefulness of a haptic virtual reality simulator with repetitive training to teach caries removal and periodontal pocket probing skills. Dent Mater J 2013;32(5):847-852

77 Papadopoulos L, Pentzou AE, Louloudiadis K, Tsiatsos TK. Design and evaluation of a simulation for pediatric dentistry in virtual worlds. J Med Internet Res 2013;15(11):e240

78 Mladenovic R, Dakovic D, Pereira L, Matvijenko V, Mladenovic K. Effect of augmented reality simulation on administration of local anaesthesia in paediatric patients. Eur J Dent Educ 2020;24(3):507-512

79 Zafar S, Lai Y, Sexton C, Siddiqi A. Virtual reality as a novel educational tool in pre-clinical paediatric dentistry training: students' perceptions. Int J Paediatr Dent 2020;30(6):791-797

80 Zafar S, Siddiqi A, Yasir M, Zachar JJ. Pedagogical development in local anaesthetic training in paediatric dentistry using virtual reality simulator. Eur Arch Paediatr Dent 2021;10:1-8

81 Naser-ud-Din S. Introducing scenario based learning interactive to postgraduates in UQ Orthodontic Program. Eur J Dent Educ 2015;19(3):169-176
82 Allaire JL. Assessing critical thinking outcomes of dental hygiene students utilizing virtual patient simulation: a mixed methods study. J Dent Educ 2015;79(9):1082-1092

83 Marei HF, Al-Eraky MM, Almasoud NN, Donkers J, Van Merrienboer JJ. The use of virtual patient scenarios as a vehicle for teaching professionalism. Eur J Dent Educ 2018;22(2):e253-e260

84 El Tantawi M, Sadaf S, AlHumaid J. Using gamification to develop academic writing skills in dental undergraduate students. Eur J Dent Educ 2018;22(1):15-22

85 Takagi D, Hayashi M, Iida T, et al. Effects of dental students' training using immersive virtual reality technology for home dental practice. Educ Gerontol 2019;45(11):670-680

86 Zafar S, Zachar JJ. Evaluation of HoloHuman augmented reality application as a novel educational tool in dentistry. Eur J Dent Educ 2020;24(2):259-265

87 Liebermann A, Erdelt K. Virtual education: dental morphologies in a virtual teaching environment. J Dent Educ 2020;84(10):1143-1150

88 Tsai R, Nguyên CĐB, Hô ĐSM, Nguyên YHT, Taylor RH. Using mobile multimedia platforms in teaching dental diagnosis. J Taibah Univ Med Sci 2020;15(4):265-271

89 Amini H, Gregory ME, Abrams MA, et al. Feasibility and usability study of a pilot immersive virtual reality-based empathy training for dental providers. J Dent Educ 2021;2021;85(6): 856-865

90 Berry MCC, de M Neto JM, de Souza MIC, Figueredo CMDS, Reher V, Evans JL. Effectiveness of technology-enhanced learning to improve periodontics educational outcomes: a systematic review. J Dent Educ 2020;84(7):830-839 